\title{
Climate Perspectives in the Intra-Americas Seas
}

\author{
Ana María Durán-Quesada $1,2, * \mathbb{C}$, Rogert Sorí ${ }^{3,4}$, Paulina Ordoñez ${ }^{5}$ and Luis Gimeno ${ }^{3}$ \\ 1 Atmospheric, Oceanic and Planetary Physics Department \& Climate System Observation Laboratory, \\ School of Physics, University of Costa Rica, San José 11501, Costa Rica \\ 2 Center for Geophysical Research, University of Costa Rica, San José 11501, Costa Rica \\ 3 Environmental Physics Laboratory (EPhysLab), CIM-UVigo, Universidade de Vigo, 32004 Ourense, Spain; \\ rogert.sori@uvigo.es (R.S.); l.gimeno@uvigo.es (L.G.) \\ 4 Instituto Dom Luiz, Faculdade de Ciências, Universidade de Lisboa, 1749-016 Campo Grande, Portugal \\ 5 Centro de Ciencias de la Atmósfera, Universidad Nacional Autónoma de México, \\ Mexico City 04510, Mexico; orpep@atmosfera.unam.mx \\ * Correspondence: ana.duranquesada@ucr.ac.cr
}

Received: 20 July 2020; Accepted: 1 September 2020; Published: 9 September 2020

check for updates

\begin{abstract}
The Intra-Americas Seas region is known for its relevance to air-sea interaction processes, the contrast between large water masses and a relatively small continental area, and the occurrence of extreme events. The differing weather systems and the influence of variability at different spatio-temporal scales is a characteristic feature of the region. The impact of hydro-meteorological extreme events has played a huge importance for regional livelihood, having a mostly negative impact on socioeconomics. The frequency and intensity of heavy rainfall events and droughts are often discussed in terms of their impact on economic activities and access to water. Furthermore, future climate projections suggest that warming scenarios are likely to increase the frequency and intensity of extreme events, which poses a major threat to vulnerable communities. In a region where the economy is largely dependent on agriculture and the population is exposed to the impact of extremes, understanding the climate system is key to informed policymaking and management plans. A wealth of knowledge has been published on regional weather and climate, with a majority of studies focusing on specific components of the system. This study aims to provide an integral overview of regional weather and climate suitable for a wider community. Following the presentation of the general features of the region, a large scale is introduced outlining the main structures that affect regional climate. The most relevant climate features are briefly described, focusing on sea surface temperature, low-level circulation, and rainfall patterns. The impact of climate variability at the intra-seasonal, inter-annual, decadal, and multi-decadal scales is discussed. Climate change is considered in the regional context, based on current knowledge for natural and anthropogenic climate change. The present challenges in regional weather and climate studies have also been included in the concluding sections of this review. The overarching aim of this work is to leverage information that may be transferred efficiently to support decision-making processes and provide a solid foundation on regional weather and climate for professionals from different backgrounds.
\end{abstract}

Keywords: climate change; cyclones; drought; ENSO; IAS; moisture transport; rainfall; SST

\section{Introduction}

The Intra-Americas Seas (IAS) region is defined as an area that includes the Gulf of Mexico and the Caribbean Sea. Jointly with the eastern Tropical Pacific, this region integrates the water masses enclosing Central America, Mexico, northern South America, and the Caribbean islands. From a large-scale perspective, continental rainfall over the IAS region, including Central America, is at times considered a part of the North American Monsoon (NAM) rainfall [1,2]. A more precise definition of 
the NAM refers to north-western Mexico and Arizona, where rainfall patterns are accompanied by the seasonal reversal of surface winds that occur along the Gulf of California [3,4]. The latter better integrates with the classical definition of the monsoon regime, based on the annual reversal of surface winds [5]. The NAM definition and its geographic domain have been subject to variations. An updated definition of the NAM is based on rainfall characteristics, where its domain is considered to include most of the IAS region [6]. In this review, the term Western North American monsoon (WNAM) refers to the precipitation over north-western Mexico and the US southwest, to avoid confusion. Located in tropical America, the IAS receives a decent share of incoming solar radiation, with an average of approximately $240 \mathrm{Wm}^{-2}$. This energy input is the primary force underpinning large-scale circulation patterns. The land-water configuration in the region highlights that ocean-atmosphere coupling plays an important role in interactions that ultimately shape regional weather and climate [7]. Amongst the many dynamic and thermodynamic feedbacks relevant to regional processes, heat fluxes are one of the main drivers accounting for energy exchange. Heat transport is far from being a near surface parameter; in the region, it is strongly connected to the loop current, and is therefore constrained to ocean bathymetry [8]. The sea surface temperature (SST) is characterised by the Western Hemisphere Warm Pool (WHWP) [9], which is the second largest warm pool on Earth. The WHWP features the seasonal SST gradients, including the seesaw between the eastern tropical Pacific (ETPac) and the Caribbean Sea. The WHWP accounts for variations in trade winds because the coupling between the meridional SST gradient and trade winds operates at the seasonal, inter-annual, and decadal time scales [10]. Trade winds dominate the low-level circulation and play a relevant role in boundary layer processes that modulate mass exchange, energy feedback, moisture transport, cyclone development, convective activity, and rainfall distribution. The main low-level structures in the region are the Caribbean Low-Level Jet (CLLJ) [11] and Choco Jet [12]. Their role to modulate rainfall patterns has been widely studied [13], as well as their connectivity with large-scale features such as the Inter-Tropical Convergence Zone (ITCZ) [14,15]. Heavy rainfall in the region is a combination of regional and large-scale processes and features, including the so-called Mid-Summer Drought (MSD) [16], ITCZ seasonal activity [14,17], tropical disturbances [18,19], and mesoscale convective activity [20].

Although some countries in the region have developed more integral economic sustainability in the technology and services sectors, the regional economy is largely dependent on agriculture. Agricultural production [21] accounts for a significant part of the national Gross Primary Product (GPP), and the main exportation products include coffee, fresh fruit, and flowers [22,23]. Agriculture is often linked with agritourism as a means of sharing the added value of sustainable production [24,25]. The dependence of regional economics on weather and climate opens up a debate on water resources management. As water resources are highly vulnerable to the effect of hydro-meteorological extremes, changes to water and climate increases the risk of an already distressed sector that has experienced the pressures of trade agreements [26]. Drought has had a significant effect on Central American and Caribbean crops as severe droughts affect approximately half of the production on average during drought $[27,28]$. Heavy rainfall and associated floods also impact crops, due to their ability to disrupt harvesting, processing, and transportation [29]. Conditions linked to El Niño-Southern Oscillation (ENSO) events have been associated with an increase in crop diseases such as coffee rust [30]. Hydro-meteorological extremes have a profound impact on regional agriculture, compromising food security, decreasing economic growth, affecting a large number of households that depend on major crops, and increasing societal risk of impoverishment [31].

Electricity generation in parts of the region relies on a steady rainfall annual cycle or the capacity to adapt production to rainfall deficits. The regional electricity matrix is comprised of a combination of different energy sources, including hydroelectric, wind farms, geothermal, thermal, and co-generation with hydroelectric and thermal. Nearly $44-64 \%$ of electricity production in Central America is thermal, with the exception of Costa Rica, where thermal production constituted $25 \%$ of the energy mix in 2010 [32]. Over the last four decades, Guatemala and Panama achieved an increase of hydropower 
capacity from 2000 to 4000 GWh and 5000 GWh, respectively. Costa Rica managed to double their hydropower capacity to nearly $7000 \mathrm{GWh}$ [33]. In the Caribbean, the energy matrix is dominated by coal, diesel, and fuel oil [34]. Central America's plans to increase their share of renewable energy production will need to confront the climate constraints posed to hydropower and wind farming, with solar energy under review due to the costs and impact of cloudiness on energy generation efficiency. In Mexico, clean energy contributed $20 \%$ of annual production $(64,848 \mathrm{GWh})$ in 2016, with hydropower representing $48 \%$ of the clean energy contribution [35]. Variability modes such as ENSO have a global impact on hydropower generation, where El Niño events decrease annual hydropower production in Central American dams [36]. The combination of hydrometeorological extremes and the growing demand are part of the regional challenges for energy security, and moreover, renewable energy production.

Access to clean water for consumption was declared a human right by the 64-292 resolution of the United Nations General Assembly. However, clean water access is recognised as one of the most neglected human rights [37]. In the IAS region, water pollution with contaminants such as arsenic [38] poses an additional threat to water access. Inequitable water access has been purported to plague Latin America and the Caribbean [39], with water-related conflicts often explored in the drylands [40,41]. The issues for water resources for agricultural production and human consumption have been drawn as a focal point. Under such circumstances, with scenarios that point to a reduction in water availability [42], the most plausible scenario appears to be an exacerbation of competition for water. Future climate projections suggest a scenario in which drylands in the Pacific coastal region are affected by greater aridity and rainfall reduction [43]. Projections also suggest a drier Caribbean by the end of the century [44], where a significant ecological impact is expected. A high risk of forest loss has been recognised for Central America, due to a projected decrease in runoff, despite potential reductions in greenhouse gas emissions [45]. Warming points to several disruptions in ecosystem behaviours, with multi-scale impacts from functional traits [46] to population dynamics [47] and forest resilience [48]. These circumstances highlight the importance of weather and climate, the variability and impacts of climate change across all areas of human livelihoods, and the vulnerability of the region as a climate change hotspot. This review aims to provide an integral overview of the climate system at a regional scale. It seeks to contribute to a body of knowledge that will benefit a broad spectrum of groups interested in understanding the main features of weather and climate that shape life in the IAS and the perspectives of climate change for the region.

\section{Large-Scale Climate Forcing}

Regional climate is the result of interactions at multiple scales, where the large scale plays a key role in the modulation of the easterly flow and the distribution of SST. The large scale sets the environment for a manifold of feedbacks, with smaller scales that define the climate characteristics at regional and local scales. We selected pressure patterns and the ITCZ to provide an overview of the relevance of these large-scale features for regional climate.

\subsection{Pressure Patterns}

During summer, circulation in North America possesses a unique pattern with a lower tropospheric cyclone over the continent. Figure 1 shows that it is accompanied by anticyclonic circulations over the oceans on its western and eastern sides, the Western Pacific High (WPH) and the North Atlantic Subtropical High (NASH) respectively, with an opposite pattern in the upper troposphere [49]. The low-level circulation in the Atlantic region is dominated by the NASH, with associated geostrophic easterlies and south easterlies in the Gulf of Mexico. This semi-permanent feature is commonly referred to as the Azores High or Bermuda High, in Europe and North America, respectively [50]. Focusing on the magnitude and location of the highest central pressure of the NASH [51] showed that the anticyclone migrates in a somewhat elliptical pattern from month to month within an area bounded by $258-408^{\circ} \mathrm{N}$ and $208-508^{\circ} \mathrm{W}$. The upper panel in Figure 1 contrasts the high-pressure systems 
between summer months June-July-August (JJA) and winter months December-January-February (DJF), in terms of intensity and extension. During summer, the NASH is enhanced, and its western ridge extends to the south-eastern US [52], inducing a strong easterly flow across the Caribbean. This flow supplies warm and humid air to feed large-scale precipitation over tropical and subtropical North America [53]. The strength and orientation of the western ridge of the NASH plays an important role in modulating the intra-seasonal variability of summer rainfall over the IAS, characterised by coupling with marine boundary layer clouds [54]. The circulation associated with the most westward extension of the NASH during July and August is linked with the MSD (described in Section 3.4.1), through the reinforcement of low-level anticyclonic flow over the Gulf of Mexico [55].

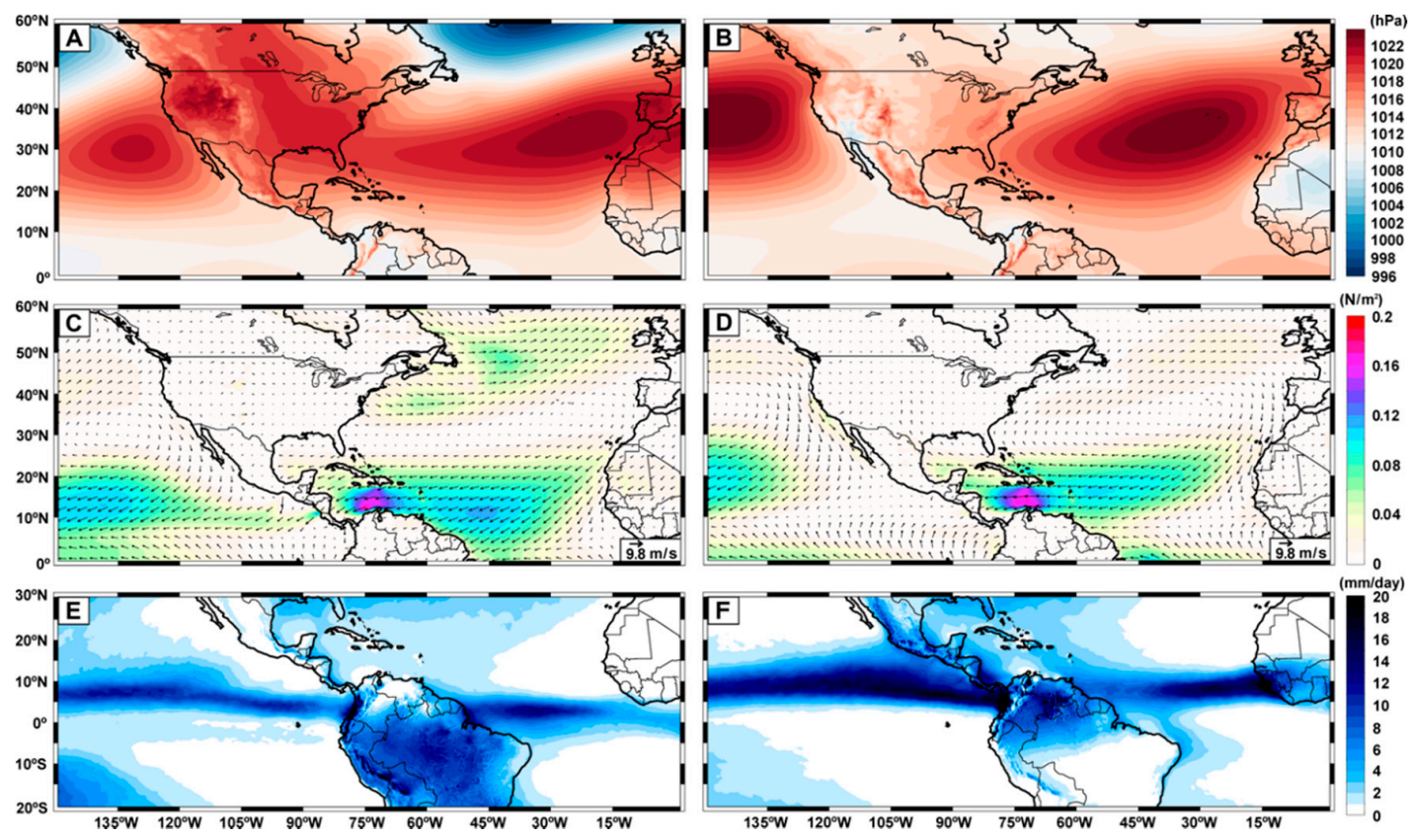

Figure 1. Mean Sea-Level Pressure for (A) DJF and (B) JJA. $10 \mathrm{~m}$ wind vectors and zonal wind shear (shaded) for (C) DJF and (D) JJA and average rainfall for (C) January and (D) July respectively, for the 1979-2019 period based on fifth generation of the European Centre for Medium-Range Weather Forecasts atmospheric reanalyses of the global climate (ERA5) data. Both (A,B) show the contrasting seasonal expansion of the North Atlantic Subtropical High (NASH) western ridge. Surface winds show the coherence of the large-scale circulation with the pressure patterns and the area that features the Caribbean Low-Level Jet (CLLJ) is observed as a maximum of zonal wind shear. Complimentary (E) and (F) show the long-term average daily regional rainfall distribution. Based on this, the seasonal migration of the Inter-Tropical Convergence Zone (ITCZ) may be observed, including its effect over continental rainfall, contrasting drier conditions overland in January.

The western ridge position of the NASH is associated with subsidence and clear skies, which makes the movement of cyclones difficult. However, when the NASH western ridge is located to the southwest of its summer climatological mean position, precipitation over the south-eastern US increases with enhanced moisture transport from adjacent tropical oceans [56]. Variations in precipitation located at the periphery of subtropical high systems have marked impacts on local circulation and the evolution of nearby weather systems. However, there have been few observational studies on precipitation in areas dominated by subtropical highs, mainly due to the limited availability of well-matched measurements. Limited impacts on local precipitation due to prevailing subtropical high conditions have been observed. According to Reference [57], precipitation was only 30\% lower under the NASH conditions than under non-NASH conditions. Whilst the impact of the NASH conditions on rainfall intensity was larger, it was still 50\% less than intensity under non-NASH conditions. Precipitation under the NASH was highly correlated with vertical motion as active up draughts, occurring even under subtropical high 
conditions. In recent decades, the NASH has been documented to intensify, causing a westward movement of its western ridge in summer. The northern hemisphere subtropical highs have been determined to intensify under warming conditions [58]. Changes in the seasonal response of rainfall to the NASH have been found to be associated with anthropogenic warming [59]. Under a warming scenario, state-of-the-art global climate models have projected that the NASH becomes more intense, with its western ridge moving further westward [60]. An intensified NASH and its westward expansion may enhance hydro-climate extremes such as heat stress and droughts in the south-eastern US [61] and is likely to affect summer precipitation in the IAS region.

\subsection{Large-Scale Circulation}

The low-level circulation in the tropics is driven by the ascending branch of the Hadley circulation as a result of latitudinal heating gradients and plays a major role for the poleward transport of heat. The analysis of the so-called trade winds and the overall global circulation goes back to the 18th century [62]. Near the equator, moist and warm tropical air rises until reaching the subtropics, where it descends towards the equator near the surface [63]. In the region, the circulation is featured by the dominating easterlies, as shown in Figure 1, middle panel. Low-level winds are forced by SST gradients and their strength is highly sensitive to SST changes [64]. Energy and mass exchange can be described by the relationship between SST and winds. The vertical velocity, which is responsible for the energy and mass transfer, is forced by diabatic heating and at the same time, the vertical velocity drives the large-scale flow within the boundary layer [65]. As a result, changes in the large-scale flow are a response to near surface heating and therefore, surface winds are driven by SST. Despite the relative simplicity, this interaction is highly complex as it involves a series of non-linear feedbacks. Further interactions between the lower atmosphere and the ocean surface can be described in terms of footprinting mechanisms. The latter is given as the tropical atmosphere is also sensitive to the subtropical SST response to atmospheric variability at different time lags [66]. Here, we highlight the fact that SST-atmosphere connectivity is not only local, and it is featured by mid-latitude tropical feedbacks as well. This is relevant to better understand that the large-scale motions and variability can be triggered by non-local interactions. A good example is the case of ENSO, for which extra tropical precursors have been identified [67]. Another way to consider the role of surface processes in the region is by means of the wind stress, given the sensitivity of the tropical circulation to this variable. Wind stress corresponds to the force (per unit area) that the airflow exerts over a surface and is a measure of the transfer of momentum between the atmosphere and the ocean, and therefore provides a quantitative estimate of the air-sea coupling [68]. Wind stress plays a major role as a key mechanism to trigger instabilities [69] as well as influence rainfall [70]. The different mechanisms and interactions acting in the region are fundamental to determine the characteristics of rainfall. In fact, it is the large scale that defines one of the most relevant structures associated to rainfall, as explained in the next subsection.

\subsection{ITCZ}

The ITCZ is a near-equatorial band of intense rainfall that extends longitudinally and can easily be identified as a cloud band over the tropics. The ITCZ describes a meridional migration that responds to the Earth's orbit, as shown for January and July in Figure 1 (lower panel), when the ITCZ is located at its lowest and highest meridional positions, respectively. This seasonal migration is crucial as the meridional position modulates the distribution of rainfall over land and ocean. In addition to seasonal migration, the mean position north of the equator is a result of cross-equatorial heat transport from ocean circulation [71]. The position of the ITCZ depends on atmospheric energy balance, whereby small changes in the energy flux can lead to larger departures from its mean position [72]. The responsiveness of the ITCZ position to temperature changes is not restricted to the tropical domain. Changes at higher latitudes may also induce the asymmetric thermal forcing that leads to ITCZ displacements. The extratropical SSTs over the Southern Atlantic Ocean play an important role in the 
northern position of the ITCZ [73]. The ITCZ is connected with large-scale processes that modulate rainfall in several regions. Its impact over Africa is mostly associated with rainfall over the southern Sahara and northernmost Sahel [74]. For the South American climate, it is linked with Amazon rainfall through complex interactions with convectively coupled Kelvin waves [75]. During DJF, inter-hemispheric teleconnection is activated by vertical wind shear over tropical South America and the western South Atlantic [76]. This facilitates the enhancement of the ITCZ convection over northern South America. The connection with South American topography shows that the ITCZ southern branch feature has feedback with the Andes cordillera, modulating precipitation over the tropical Pacific [77]. Over Colombia, the ITCZ increases rainfall for one of the rainiest places on Earth-the Lloró [12]. For Central America, the ITCZ is a dominant feature of the annual hydrologic cycle and modulates moisture transport from the eastern tropical Pacific [78,79]. Further interactions between the ITCZ and the CLLJ have been found to partially trigger a displacement of the ITCZ centre of mass, ultimately spreading the rainfall distribution [14]. Given the relevance of the ITCZ position for rainfall distribution, changes that may impinge variations in atmospheric energy balance are crucial to understanding how anomalous migrations of the ITCZ may affect rainfall. The influence of the ENSO is one of the most researched connections to the ITCZ anomalous meridional shifting. ENSO may increase the wind stress over the western equatorial Atlantic, modifying Atlantic equatorial ocean dynamics and providing a mechanism to couple rainfall pattern changes with ITCZ movements [80]. Over the IAS, the ENSO has been associated with a westward movement of the ITCZ, decreasing rainfall activity over the Pacific coast and increasing dry conditions.

\section{Regional Climate Features}

\subsection{WHWP}

SST gradients between the Caribbean and the eastern tropical Pacific play a role in rainfall distribution [81]. The regional SST is characterised by the WHWP, a warm pool defined as the area enclosed by the $28.5^{\circ} \mathrm{C}$ isotherm that exhibits a marked seasonal cycle [9]. Its role in regional climate is strongly linked to heat balance [82]. The evolution of WHWP components, namely the eastern Pacific (EPWP) and Atlantic (AWP), may be considered independent as they respond to different mechanisms, with the former being characterised by its subsurface oceanic dynamics [83]. The EPWP develops earlier than the AWP, and its onset is seasonally synced with coastal shoaling that marks the development of the Costa Rica Dome (CRD) [84] after March. There is an amplification of its spatial extension across the Central American Pacific coast as far as $120 \mathrm{~W}$ on average, until August [85]. In addition to enclosing the biologically important CRD, the EPWP modulates Central American rainfall, triggering deep convection. It is connected with the ITCZ and further activation of intense deep convection [86] as well as cyclone development [87]. Its Atlantic counterpart starts its onset in June and continues expansion to the southern Caribbean by September, with a peak between July and September. The development of the AWP is mainly constrained by boundary layer coupling and modulated by air-sea heat fluxes [88]. Warm waters enclosed by the AWP provide a major part of the moisture transported within the region, playing a relevant role in rainfall contribution $[79,89]$. The AWP acts as a moisture supplier to the NAM in connection with the bridge established between the CLLJ and the Great Plains low-level jet [90]. The AWP is important in terms of its regional dynamics beyond its role as a moisture source, as regional rainfall is dependent on the AWP extension. Anomalous extensions of the AWP are associated with a milder MSD, while a smaller AWP enhances the MSD, increasing drier conditions over the Central American Pacific coast [91]. The AWP influences the cyclone development season [92], and the enlargement of the AWP corresponds to a reduced vertical wind shear, which allows an intensification of Atlantic hurricane activity. The activity of both components of the WHWP are responsive to interannual variability [93]. Temperature changes in the WHWP area impose a modulation in the WHWP dynamics, impacting on rainfall. Under a warming 
climate, temperature changes are predicted to cause variations in warm pool extensions and trigger variations in the rainfall distribution within the IAS domain.

\subsection{Low-Level Circulation}

The IAS circulation is dominated by the descending branch of the Hadley cell, and the low-level flow is controlled by trade winds. In the regional context, low-level jets (LLJs) are fundamental mechanisms to modulate the regional climate and inter-hemispheric interactions. Globally, LLJs are known to be connecting to background circulations, modulating water vapour supply during extreme events, and inducing variations in the cyclone development potential through wind shear control. LLJs may be classified based on wind speed and height as boundary layer (height $<850 \mathrm{hPa}$ ) and free atmosphere $(600<$ height $<850)$. The free atmosphere LLJs influence synoptic systems and boundary layer LLJs modulate the synoptic and high-low-pressure transitioning systems [94]. In the region, the main low-level structures are the CLLJ and the Choco jet, whereas the development of smaller-scale features results from interactions between the easterly flow and regional topography. This wind-topography interaction allows the seasonal development of gap winds over Tehuantepec, Papagayo, and Panama (as observed from the blue shaded regions on the Pacific coast shown for January and February in Figure 2). These gap winds are important to enhance offshore upwelling in the easternmost tropical Pacific and have a relevant biological role. Here, we focus on the CLLJ and the Choco jet as the two most prominent features of low-level circulation in the region.
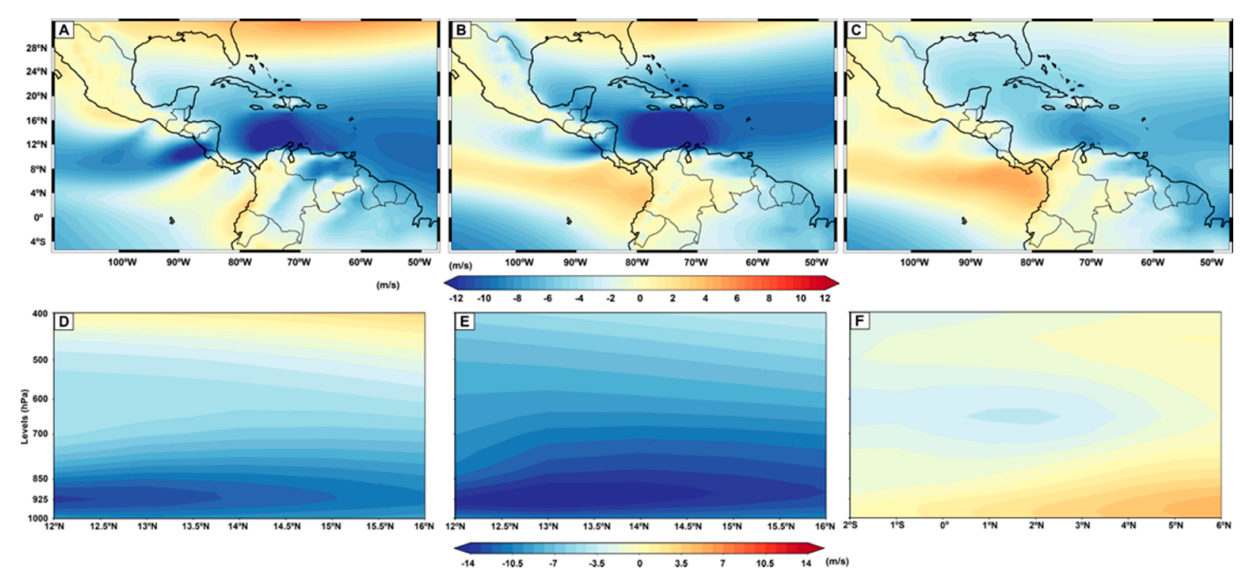

Figure 2. Mean zonal wind in $925 \mathrm{hPa}$ for (A) January, (B) July, and (C) October. The mean annual vertical cross-section (1000-400 hPa) for $80^{\circ} \mathrm{W}-70^{\circ} \mathrm{W}$ from $12^{\circ} \mathrm{N}$ to $16^{\circ} \mathrm{N}$ for (D) January, (E) July, and $(\mathrm{F})$ mean annual vertical cross-section $\left(1000-400 \mathrm{hPa}\right.$ ) for $90^{\circ} \mathrm{W}-80^{\circ} \mathrm{W}$ from $2^{\circ} \mathrm{S}-6^{\circ} \mathrm{N}$ for October. Data from ERA5.

\subsubsection{CLLJ}

The CLLJ $[11,94]$ is defined as an intensification of the easterly flow at approximately $12-15^{\circ} \mathrm{N}$ and $75-70^{\circ} \mathrm{W}$, with maximum wind speeds reaching $12 \mathrm{~ms}^{-1}$. It has a marked annual cycle with a primary maximum between July (Figure 2B) and August, a secondary peak between January (Figure 2A) and February, and a minimum in October (Figure 2C). During the secondary peak, the jet core is constrained below $925 \mathrm{hPa}$ (Figure 2D), whereas for the primary peak, the core extends up to $700 \mathrm{hPa}$, as shown in Figure 2E [95]. This difference is important, as during the July to August maximum, the CLLJ has an extended connection as a free atmosphere LLJ, allowing interactions with circulations at higher levels. In contrast, during the secondary maximum, the CLLJ is largely constrained to act within the boundary layer domain, and its interactions have greater limitation. One of the main contributions of the CLLJ is as a regional moisture conveyor associated with rainfall over Central America, northern South America, and the Great Plains region [78,79]. The connectivity with the free atmosphere as the CLLJ reaches the primary maximum provides a bridge that allows its interaction with the ITCZ. The latter allows 
the modulation of regional rainfall through the displacement of the ITCZ meridional position [14]. Variations in the vertical structure of the CLLJ during boreal summer months regulate cyclone activity in the tropical Atlantic, with an enhanced CLLJ increasing the wind shear that suppresses cyclone formation [96]. Furthermore, the CLLJ plays a determinant role in the development and intensification of easterly waves [97]. The CLLJ is subject to variability at different time scales. At high frequencies, the CLLJ is a more efficient mechanism to transfer the influence of the Madden-Julian Oscillation (MJO) to the easterly wave dynamics over the eastern Pacific [98]. At inter-annual scales, the ENSO is the variability mode linked to the larger impact for the CLLJ, as warm (cold) ENSO conditions are related to a stronger (weaker) CLLJ during JJA. The relationship between ENSO and CLLJ is different for DJF and JJA [11,95]. This has further implications for rainfall patterns for a number of reasons. First, anomalous moisture transport is enhanced such that during the first stage of the rainy season, the Caribbean moisture source is diminished, while transport for Central America becomes stronger during the primary maximum [79]. Second, the ITCZ position is shifted, and third, the wind shear reduces the potential for cyclone formation. The increase in moisture supply does not necessarily cause wetter conditions as the instabilities required for convection to activate are weakened by intense winds, and the ITCZ also shifts away to the ocean [79].

\subsubsection{Choco Jet}

The Choco jet is often studied for its association with heavy rainfall patterns, making north-western Colombia one of the rainiest regions on Earth. The Choco jet was first introduced as an extension of the south-westerly cross-equatorial flow in Reference [99]. The annual cycle of the Choco jet is defined by the regional SST gradient, which allows the Choco jet to transition from its weakest intensity during February-March to its peak in October [12]. In contrast to the CLLJ, the Choco jet exhibits only one peak, and its intensity is nearly half the CLLJ maximum intensity at its primary maximum. The Choco jet structure is confined below $850 \mathrm{hPa}$, so that the Choco jet may be considered a purely boundary layer LLJ. Although, it has often been analysed in terms of an intensity index defined as the longitudinal average of wind speed, as that the Choco jet also exhibits meridional displacement [15]. This has been traditionally neglected in previous generation reanalysis, as a coarse resolution reanalysis does not adequately reproduce this feature. Variations in the meridional positioning of the jet core are important, as shifting may modulate moisture transport and disrupt interactions with other systems, creating an impact on rainfall distribution. The Choco jet advects moisture from the eastern tropical Pacific, which largely dominates the hydro-climatology of northern South America [100-102]. Moisture supply from the Choco jet is also important for the Central American Pacific coast [78,79,103]. The relevance of the Choco jet is not restricted to moisture transport, as the Choco jet is also connected with deep convective development over the region [104]. Connectivity between the Choco jet and deep convection is complex and involves interactions with the ITCZ, and this may be connected to the meridional positioning of the jet core [15]. A recent experimental campaign was conducted to investigate the dynamics of the Choco jet and its role in regional rainfall. CHOCO-JEX was developed as an inter-institutional effort led by Colombia to assess the observational aspects of Choco jet dynamics [105]. The effect of inter-annual variability on the Choco jet was a decrease in intensity during warm ENSO conditions, with a corresponding rainfall decrease [106]. The ENSO modulates rainfall extremes, where warm ENSO is linked with drying and a cold ENSO is associated with heavy rainfall via moisture transport enhancement, as per the 2010-2012 anomalous wet season [101]. The Choco jet response to the ENSO is the inverse of the response from the CLLJ. This also explains the wetter conditions during the cold ENSO over the Pacific coast of Central America where the Pacific moisture supply had increased [79].

\subsection{Moisture Transport}

Moisture transport in the IAS is often discussed in terms of the WNAM [107], where rainfall is favoured by moisture transport from the Gulf of Mexico, with the eastern tropical Pacific, 
Caribbean Sea, and the Gulf of Mexico playing a minor role [108]. An accurate quantification of evapotranspiration and moisture recycling is constrained by the complex surface and observational data availability $[109,110]$. Moisture source diagnostics, related to the NAM and WNAM, have been performed using observations [111], reanalysis, [112], modelling [113], and the combination of water vapour tracers-enabled models and water-stable isotopes [4,114]. Despite the association of the IAS for WNAM development, based on the connection between the GPLLJ and the CLLJ, the IAS waters also play a key role. Complimentarily, here, we focus in moisture transport over the IAS.

Figure $3 \mathrm{~A}$ shows the maximum of vertically integrated water vapour during the rainiest period of the year, which reduces during the dry season despite still maintaining a good amount of moisture in the southernmost part of the IAS (Figure 3B). The mechanisms for regional moisture transport have long been explored. A northward transport of moisture across the $20^{\circ} \mathrm{N}$ latitude with a southward shift of minimum moisture transport during the boreal autumn was identified in Reference [115]. The results of previous studies have highlighted the relevance of LLJs and the ITCZ to modulate moisture transport and rainfall [116]. The Caribbean Sea is the main source of moisture for Central American rainfall, whilst concurrently modulating regional moisture transport dynamics. Transport from this source is very efficient and transport peaks between 4 to 6 days [79]. An independent analysis of moisture transport using physical tracers [117] showed consistency of previous backward trajectories and vertical integrated moisture flux-based analysis. The Caribbean Sea contributes to rainfall in northern South America with descending flow from the CLLJ that connects to a low-level structure in the Venezuelan plains [101,102]. Continental sources of moisture for Central America are identified as local moisture recycling and northern Colombia, with the latter allowing connectivity with the Amazon to enhance inter-hemispheric bridges. However, the quantification of local evapotranspiration and its role in recycling remains an open problem, limited by data scarcity and surface complexity.
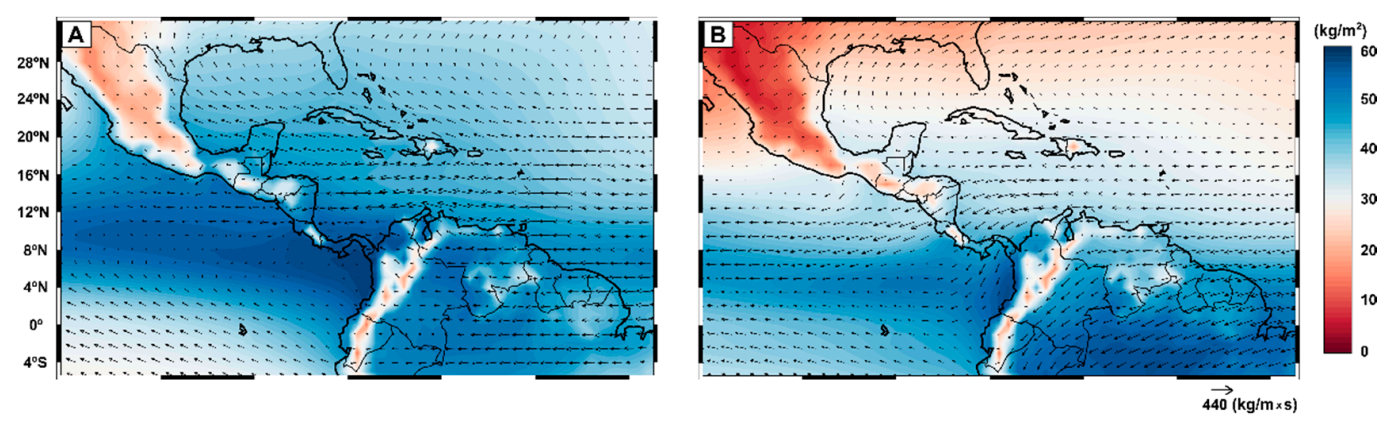

Figure 3. Mean total column water vapour (shaded) and the vertically integrated water vapour flux (arrows) for (A) May-October and (B) November-April for the 1979-2019 period based on ERA-5 data. A high moisture content was observed between May and October with transport mostly directed along the storm track, following the development of the meridional branch of the CLLJ. In contrast, a reduced moisture content is featured in the November-April period. Here, transport is directed across Central America, with the cross-isthmus transport characteristics of a drier season.

Moisture transport is sensitive to the variability modes that drive changes in the SST and LLJs. The moisture supply response to the ENSO is modulated by the response of the CLLJ and the Choco jet, so that moisture supply decreases (increases) from the Caribbean (eastern tropical Pacific, ETPac) during the first stage of the rainy season. It is then enhanced from the Caribbean between July and September and decreases from the ETPac in August [79]. The role of anomalous moisture transport during ENSO events has also been confirmed by changes observed using modelling [118] and physical tracers [119]. The effect of the North Atlantic Oscillation (NAO) has been suggested to have a more significant impact on the structure of moisture transport directly acting over the CLLJ rather than the intensity of moisture sources in the Caribbean. This has an overall effect of increasing transport to Central America during NAO negative phases. In this sense, the location at which the maximum transport arrives is also modulated by NAO-induced variations. At lower frequencies, the impact of 
the PDO consists of an intensified ENSO pattern that induces a further weakening (enhancement) of moisture transport from the Caribbean (ETPac) during the first stage of the rainy season. At higher frequencies, the MJO dominates transport variability as it acts as a force for the CLLJ. Its effect on moisture transport consists of a strong intensification of moisture supply during the rainy season for negative values of MJO-filtered Outgoing Longwave Radiation, strengthening an easterly wave-like pattern moving to the west [118]. The main impact of moisture transport variability is the modulation of regional rainfall distribution. This has motivated the quest for a better understanding of transport dynamics to improve forecasting capabilities and better interpret projected future climate scenarios.

\subsection{Rainfall}

The regional distribution of rainfall is defined by moisture transport, the migration of the ITCZ, cyclone development, passage of tropical disturbances, mesoscale convective systems (MCS) development, and mid-latitude interactions (e.g., cold surges). On average, rainfall distribution is bimodal with a marked dry season and the reduction of rainfall during the peak of the CLLJ in July (see area averages in Figure 4). This bimodal distribution is more prominent on the Pacific coast, as moist air flow from the Caribbean interacts with the mountain range, and the Caribbean slope is wetter in contrast with a drier Pacific slope. Complementary rainfall over the Caribbean is dynamically influenced by the Pacific. Interactions between both water masses drive fluctuations observed in rainfall patterns [120] and are modulated by large-scale pressure patterns and temperature gradients [121].

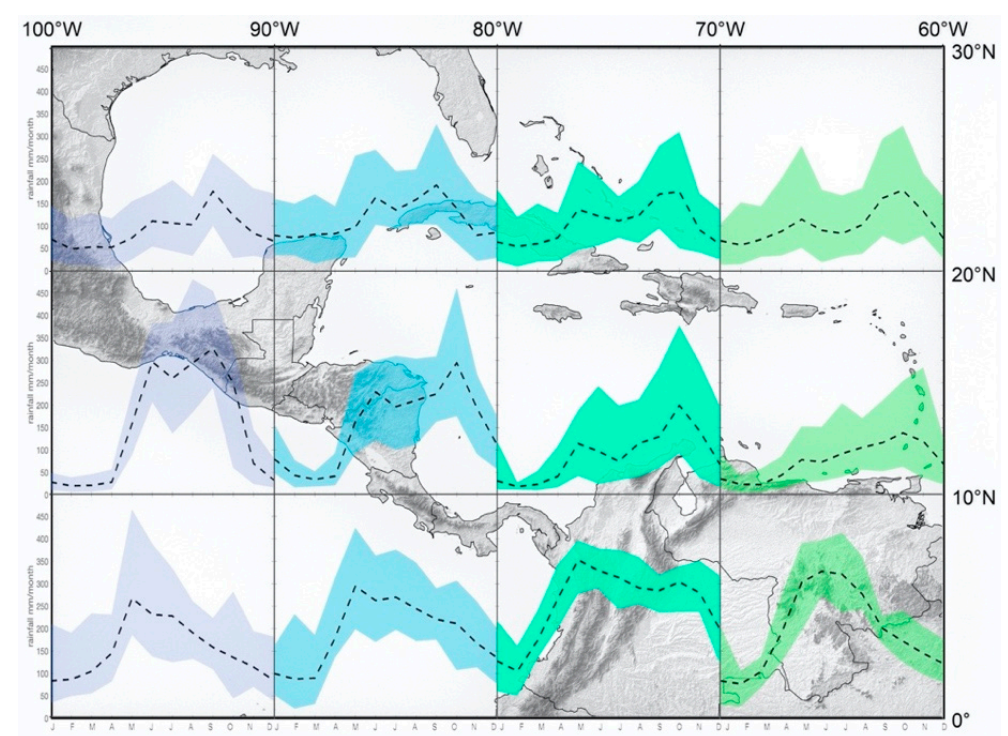

Figure 4. Average annual cycle of rainfall for contiguous $10^{\circ} \times 10^{\circ}$ areas as shown in the boxes based on monthly Global Precipitation Measurement (GPM) for the 2001-2019 period.

\subsubsection{Rainfall Distribution and the MSD}

The annual rainfall cycle is strongly controlled by the migration of the ITCZ. The central and western Colombian annual precipitation cycle results from the passage of the ITCZ. This consists of distinct rainy seasons (April-May and October-November) and drier or less rainy conditions (December-February and June-August) [122,123]. From the northern Caribbean coast of Colombia to southern Mexico, the rainfall annual cycle is dominated by a relatively dry season from November to April, and a wet season from May to October. Further north, the bulk of annual rainfall over much of Mexico occurs during a four-month period (June to September) [124]. Rainfall decreases during the boreal summer months in the Pacific coast of Central America. Therefore, much of the IAS region features a rainy season with periods that are above or below average precipitation. Rainfall seasonality is marked by two precipitation peaks: May-June and September-October. In general, this features a bimodal distribution with a relative minimum precipitation during July and/or August. This relative 
minimum is known as the MSD and corresponds to a minimum in convective activity. Terms such as canicula (regardless of the name being defined for temperate climate) and veranillo have been used locally to refer to this condition depending on the region of occurrence $[16,125,126]$. Figure 4 shows the long-term rainfall annual cycle (dotted lines) and the maximum and minimum values (defined by the shaded area) averaged over $10^{\circ} \times 10^{\circ}$, upon which the bimodal distribution that features rainfall may be observed. The amplitude of the MSD varies across the domain with northern Central America and the Caribbean, exhibiting the largest rainfall decrease during the boreal summer.

The MSD is the result of a rainfall-enhancing mechanism that occurs twice because of the biannual crossing of solar declination [127]. The northward displacement of the ITCZ following the seasonal march of the SST and the westward extension of the NASH have also been identified as forcing mechanisms of the MSD $[55,128]$. The variability of the CLLJ and associated direct circulations are a key element in MSD development. Several studies have characterised the MSD over Central America, the Caribbean islands, and Mexico, finding high spatio-temporal variability [126,129-131]. Large-scale dynamics, dominated by low-level atmospheric patterns and orographic forcing associated with steep topography, generate distinct MSD signatures in the region. The MSD is highly sensitive to the main variability modes that affect the region. At higher frequencies, the MJO [132] is a key modulator of the intra-seasonal variability of the MSD [133]. Changes in intra-seasonal variability are relevant as they modulate the onset and offset of the MSD, having a significant impact on the lengths and intensity of the rainy seasons. Information on the onset and offset of the MSD is critical for agriculture, hydropower electricity generation, and water resources management. At interannual scales, the ENSO modulates MSD variability through variations in the CLLJ (see Section 4). Although heavy rainfall is a feature of the region, drier periods are equally important as they play a major role in agriculture, energy, and regional economy in general. Understanding the dynamics of the transitioning of dry-wet seasons, its variability, and long-term trends is fundamental for planning.

\subsubsection{Tropical Cyclones}

Tropical cyclones (TCs) represent an economic and societal threat for the western North Atlantic basin, including the US Atlantic Coast, coastal Mexico, Central America, and the Caribbean [134]. Even when storm surges account for the largest number of casualties, many of the highest fatality events in the Atlantic basin are rain-induced disasters on steep terrains in the Caribbean and Central America linked with landslides. The indirect effect dominates the impact of TCs in Central America [135]. However, direct impacts also occur when the TC landfall is located in the isthmus. Although the landing of TCs in Central America is infrequent, TCs have been recorded to affect Central America with landfalls as southern as Nicaragua and Costa Rica [136-139]. The tropical North Atlantic (TNA) and the eastern North Pacific (ENP) are regions of high tropical cyclogenesis. TCs generally develop over oceans with SST $>26^{\circ} \mathrm{C}$, from pre-existing atmospheric disturbances, and often move out of these regions into higher latitudes. TC genesis may be a result of nearly classic baroclinic development [140], the interaction of EWs or other low-level disturbances with tropical upper tropospheric disturbances [141-143].

The annual distribution of TCs is shown in Figure 5 for the Atlantic (A) and eastern tropical Pacific (B), from which the interannual variability of the TC intensity has been highlighted. For the TNA basin, the main development region is defined as the TNA south of $21^{\circ} \mathrm{N}$ and the Caribbean Sea. In this area, cyclonic activity mainly originates from the African easterly waves (AEWs) that propagate from West Africa towards the TNA. Winds in the mid and upper atmosphere may steer up cyclones to the north; when TCs reach latitudes near $30^{\circ} \mathrm{N}$, they often move northeast. On average, AEWs account for nearly $60 \%$ of the Atlantic basin tropical storms and non-major hurricanes, and nearly $85 \%$ of hurricanes of strong intensity $[144,145]$. The Caribbean islands, the Caribbean coast of Central America, and the Yucatan Peninsula experience the direct influence of TCs, particularly, the most severe systems as they move along the storm track. These systems form at a low latitude, east of $100^{\circ} \mathrm{W}$, and travel slowly westward, where they reach their highest intensity. While the origins of ENP tropical waves continue to be debated, they are thought to originate from reinvigorated AEWs that have propagated over the 
Central American isthmus [97,146]. On average, the eastern Pacific hurricane season extends from May to November, commencing earlier than the Atlantic basin and experiencing the maximum amount of activity near $17^{\circ} \mathrm{N}, 108^{\circ} \mathrm{W}$ (southwest of Manzanillo, Mexico). Of the TCs recorded over the ENP tropical cyclone basin between 1949 and 2006, roughly 20\% are estimated to have caused tropical storm force winds along the Mexican coastline. TCs affecting land areas other than Mexico in the ENP are rare. There are only four TCs that have affected areas of the Central American Pacific coast based on the historical records.

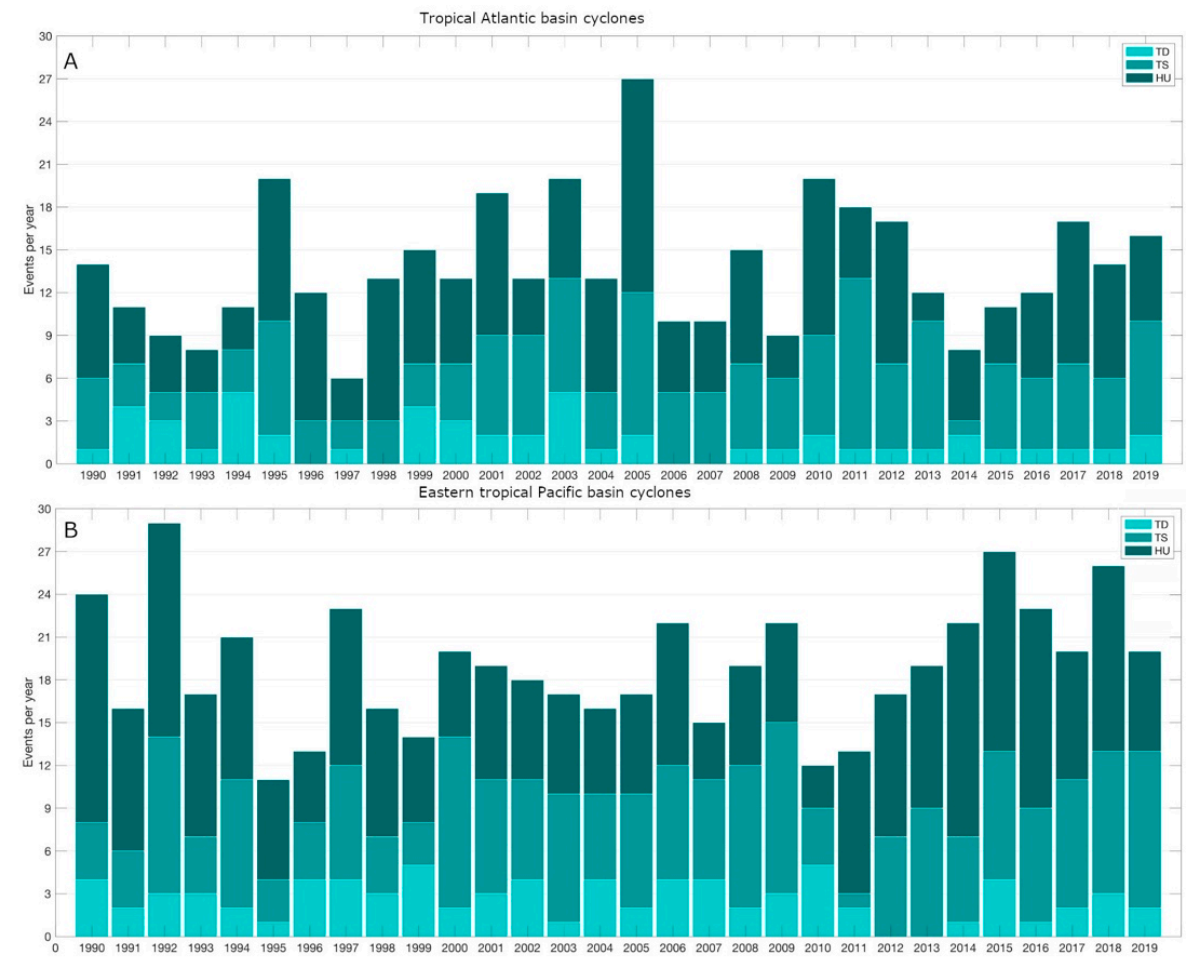

Figure 5. Annual distribution of TCs in the (A) Atlantic and (B) eastern tropical Pacific based on the historical HURricane DATa 2nd generation(HURDAT2) record available at the National Hurricane Center (NHC) (http://www.nhc.noaa.gov) for the 1990-2019 period. The occurrence of hurricanes affecting the Central American coast features a large number of severe events hitting the Caribbean coast. This demonstrates the indirect and direct relevance of these systems.

\subsubsection{Mesoscale Convective Activity}

Mesoscale Convective Systems (MCS) are the largest form of organised deep convection and storms. They are able to produce rainfall over large extensions, are a major cause of flooding, and connect atmospheric convection to larger-scale atmospheric circulation [147]. The stretched building block model [148] explains how large scales modulate the duration of shallow, deep, and stratiform anvil clouds in the MCS. Different studies analyse the connection between MCS and waves ahead of convective initiation in the MCS and the links between MCS and tropical cyclonegenesis [149-152]. A relevant MCS region over Central America features MCS in the 3000-40,000 km² range, similar to tropical South America [153]. Over land, MCS are more frequent in the evening, and the maximum rainfall occurs after the peak of heating [153]. Different studies have focused on convective development over the Panama Bight that has been linked with the Choco jet. The strengthening of the Choco jet enhances the development and propagation of convective disturbances in the region, providing for favourable conditions for MCS activity in the area [104]. In addition to the Choco jet forcing, other conditions are required for the MCS to develop, including the interaction of the ITCZ with tropical easterly waves [154-156]. The contribution of MCS development to Central American rainfall exceeds 70\% of total rainfall in the Pacific coast [157]. As the Pacific coast is a dry area, this implies that rainfall in this 
area is highly dependent on MCS activity. As the ITCZ reaches its northernmost position, MCS activity increases and development is characterised by a marked difference between rainfall type (convective versus stratiform) as a result of differences in latent heating [158]. Rainfall over the region is featured by a larger size of the stratiform part of the storm compared to the convective core [159]. The position of the convective nuclei is extremely important to define areas under flood risk, and the variability and trends of the MCS are key to assess the impacts of extreme events in the region.

\section{Climate Variability}

This section describes the influence of the main modes of climate variability that affect the IAS. From high to lower frequency modes, several studies have highlighted the modulation of rainfall patterns and intensity through the main variability modes. With the MJO leading to intra-seasonal variations and ENSO, this accounts for the largest impact at the inter-annual scale.

\subsection{High-Frequency Variability}

The MJO is a dominant mode of intra-seasonal variability over the tropics and is characterised by a planetary-scale propagation of organised tropical deep convection that originates over the tropical Indian Ocean on a time scale ranging between 30 and 60 days [160]. The MJO travels eastward, equatorially trapped during the boreal winter, and is characterised by a prominent northward propagation during the boreal summer. During this period, anomalous rainfall was first evident over the Indian Ocean and remained apparent while it propagated over the warm western and central tropical Pacific oceans [161]. This pattern generally becomes vague over the cooler eastern Pacific, with the exception of the region off the west coast of Central America. It also reappears occasionally at low amplitude over the tropical Atlantic. In the IAS, the MJO has a strong influence on rainfall distribution and often modulates the onset of the rainy season, inducing variations in the length of the rainy seasons and the MSD. A significant relationship exists between Pacific MJO activity and rainfall over Central America and Mexico during June-September [162]. In the most affected regions, the daily rainfall amount doubled between periods when the MJO was enhancing and suppressing rainfall [163]. These changes were driven primarily by variations to mean large-scale circulation. The MJO can influence TC activity in the ENP and TNA basins during the boreal summer, enhance EWs activity [164] and tropical cyclogenesis [163,165], and modulate convectively coupled Kelvin waves [166]. The background state of the east Pacific is modulated by the MJO, and the CLLJ alters the count and spatial characteristics of EWs [98]. The MJO modulates TCs and hurricanes over the Atlantic during the peak months of the Atlantic hurricane season and it is linked to the passage of more intense hurricanes near Puerto Rico when both annual and MJO-filtered wind shear are in the eastern phase [167]. According to Jury [167], the MJO affects the Caribbean circulation and the convective signal as the MJO reaches the Caribbean $\left(10-15^{\circ} \mathrm{N}, 60-80^{\circ} \mathrm{W}\right)$ from a transition area of the equatorial east Pacific $\left(2^{\circ} \mathrm{S}-7^{\circ} \mathrm{N}, 110-130^{\circ} \mathrm{W}\right)$, which mainly occurs from September to November, when Caribbean SST exceeds $28^{\circ} \mathrm{C}$ and the equatorial trough lies northward. The MJO influences the timing of the MSD in Costa Rica. It has been determined that the first and the second rainfall peaks occur more often during MJO phases 1 and 8, respectively [168]. The influence of the MJO is a consistent feature across Central America and Mexico [130]. To the best of our knowledge, unlike other areas, the MJO modulation of the onset and demise of rain periods in the IAS is still an open problem.

\subsection{Interannual Variability}

The ENSO is the result of coupled ocean-atmosphere dynamics in the tropical Pacific [169], and, is the leading mode of interannual variability. It is associated with SST shifts, circulation, and rainfall patterns across the globe [170]. After the El Niño in 1997-1998, interest in the impacts of El Niño over the IAS region had increased. During El Niño boreal winters, precipitation increases over north-western Mexico (orange shading in Figure 6A) due to a southward shift in the subtropical jet stream position [171]. Conversely, rainfall decreases around the isthmus of Tehuantepec and the 
Caribbean coast of Central America [13,171] (blue shading in Figure 6A). During warm (cold) ENSO, the zonal easterlies increase (decrease) over the isthmus [172], decreasing (increasing) precipitation over the Pacific slope of Central America. Rainfall variations are a response to the modulation of moisture transport from the Caribbean [79] and changes in the ITCZ meridional position forced by the ENSO. During the boreal summer, strong El Niño events are associated with drier than normal conditions in southern and central Mexico, Central America, and parts of the Caribbean. Along the Caribbean coast in Central America, El Niño leads to above normal rainfall [173]. A negative correlation exists between the intensity of the CLLJ and precipitation (strong jet with weak precipitation and vice versa) in Central America and southern Mexico [11]. In these cases, the El Niño results in an anomalous descent over southern Mexico that inhibits convection [174,175]. The ENSO affects the genesis, tracks, intensity, and lifetimes of TCs in the ENP and TNA, through changes in SST, vertical wind shear, and relative vorticity induced by wind anomalies in the lower troposphere and changes in upper-tropospheric temperatures $[176,177]$. El Niño inhibits the formation of TCs through enhanced vertical wind shear, subsidence, and reduced relative humidity in the tropical Atlantic [178]. The contrast of ENSO phases for TC activity is shown in Figure 6B-D, with enhanced (decreased) activity over the ENP (TNA) during a warm ENSO. In contrast, during a cold ENSO, TCs are intensified when they reach the Caribbean coast of Central America by the reduction of vertical wind shear. The impact of the ENSO is often associated with rainfall extremes. Assessments of the impacts of El Niño associated with disasters between 1972 and 2010 indicate damages of approximately 2.904 and 1.111 billion USD in losses in the agricultural and forestry sectors [179].
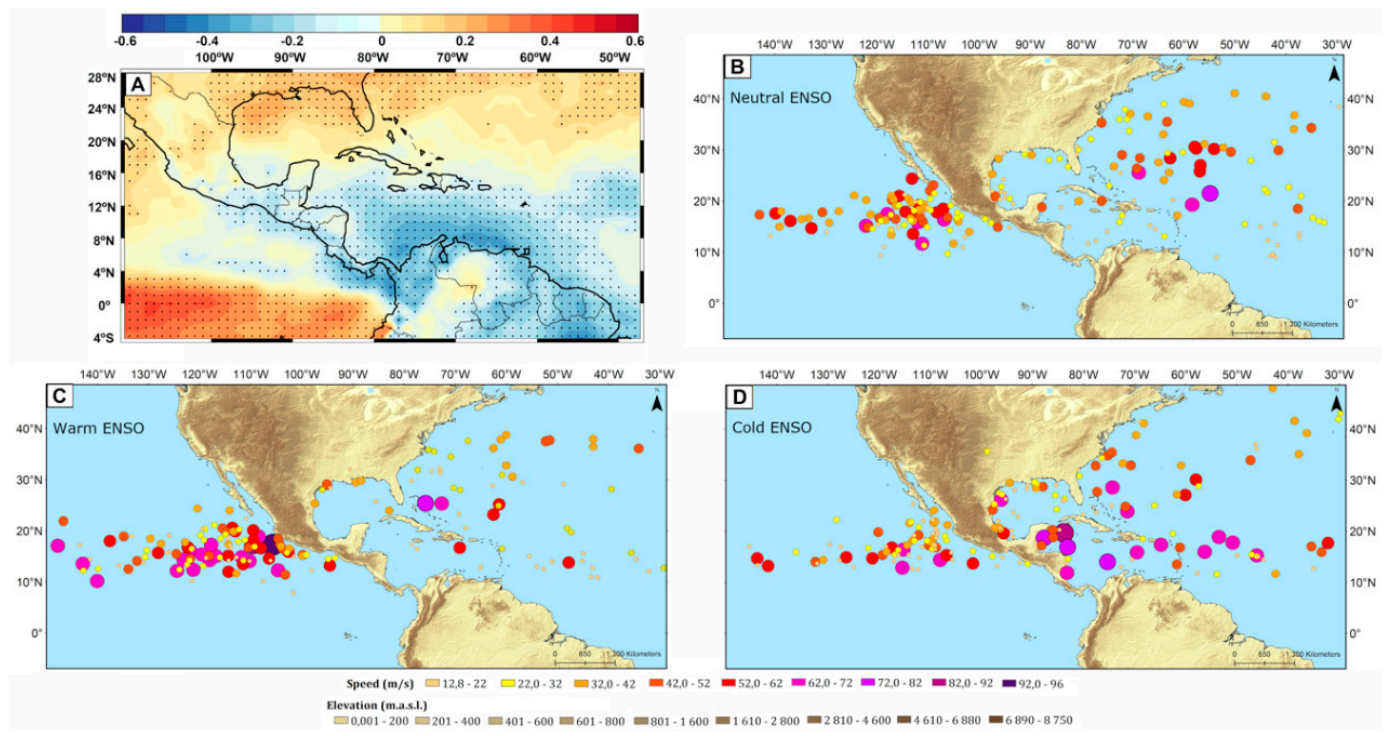

Figure 6. (A) Correlation between the Bivariate El Nino- Southern Oscillation Timeseries BEST index and ERA-5 rainfall anomalies (dotted areas indicate statistically significant values, blue shade for warm El Niño-Southern Oscillation (ENSO) lead rainfall reduction, and orange shade for rainfall increase during warm ENSO). Tropical cyclones (TCs) composites for (B) warm (1983, 1987, 1992, 1997, 2015), (C) cold (1988, 1998, 1999, 2007, 2010), and (D) neutral (1981, 1990, 2003, 2012, 2014) ENSO years based on the ENSO 3.4 region sea surface temperature (SST) anomalies for the Atlantic and eastern tropical Pacific based on the HURDAT2 archive. The results highlight differences in the amount and intensity of TCs depending on the ENSO phase, with warm (cold) ENSO featuring reduced (enhanced) cyclonic activity over the Caribbean with a contrasting pattern for the eastern tropical Pacific (ETPac).

Although the ENSO leads to interannual variability, other modes also affect regional climate. The Atlantic meridional mode (AMM), which describes the meridional gradient between northern and southern tropical Atlantic SST [180], also influences the activity of Atlantic TCs [181]. A negative AMM phase (cool northern and warm southern tropical Atlantic SST anomalies) inhibits Atlantic TCs. Strong phases of the ENSO and AMM may amplify or dampen the influence of one another on 
Atlantic TCs [182,183]. In terms of mechanisms, ENSO and AMM impacts shear with La Niña (El Niño) and positive (negative) AMM, driving low (high) shear anomalies with the advantage of AMM predictability compared to ENSO [184]. A synergy between the AMM and ENSO modulates deep convection in the tropics [185], with increases to regional rainfall for a positive AMM (Figure 7A).

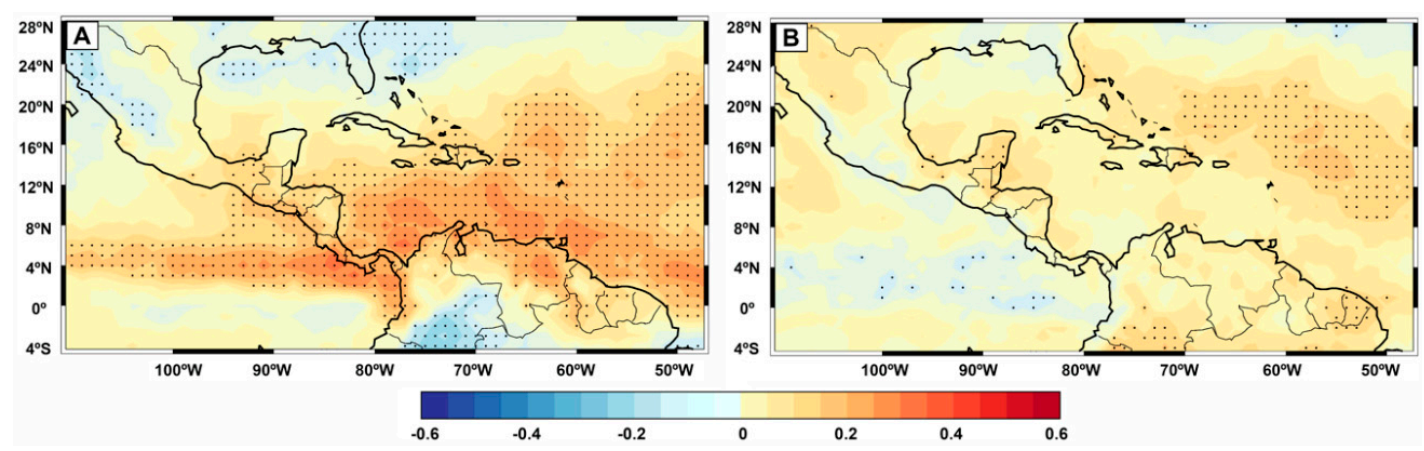

Figure 7. Correlation between the (A) Atlantic meridional mode (AMM) index and (B) NAO index computed with ERA-5 rainfall anomalies, with dotted areas indicating significant correlations $p<0.05$. The blue shading shows areas in which positive AMM and NAO leads to rainfall reductions, while orange shading corresponds to regions that experience rainfall increases during positive AMM and NAO phases.

The NAO [186] has direct impacts at mid and high latitudes, although this mode may also affect the tropical Atlantic (see Figure 7B). During summer, a positive NAO causes stronger trade winds and shifts the ITCZ southward. The NAO influence over the Caribbean Sea and the Gulf of Mexico is generally weak, with an exception during spring [187], when the Caribbean and Central America rainfall is highly influenced by the TNA variability. In the northern Antilles, a larger signal relates to a combination of ENSO and NAO phases. A warm ENSO and a negative NAO are associated with wetter conditions, while a cool ENSO and a positive NAO create drier conditions [188]. A linear combination of these three modes (ENSO, NAO, and AMM) reproduces a substantial amount of the variability in the observed mass fields, vertical wind shear, and relative humidity over the TNA.

\subsection{Decadal and Multi-Decadal Variability}

The spatial pattern of the Pacific Decadal Oscillation (PDO) is similar to that of ENSO, and it is not entirely clear whether the PDO is a truly independent mode $[189,190]$. Although the impacts of the PDO occur mainly in the North Pacific, it also affects the tropics. There is a correlation between the PDO index and precipitation anomalies in the IAS region [191]. Warm PDO phases are associated with anomalously dry periods in Central America and northern South America, whilst the same phase was related to wetter than normal conditions in Mexico. It is important to note that as a Pacific mode, the PDO has the potential to act jointly with ENSO, and depending on the phasing, the PDO can enhance ENSO conditions. Precipitation in Mexico between November and April remains in phase with the PDO and positive (negative) PDO increases (decreases), while during May-October the relationship is reversed [192]. The combined effects of the PDO and ENSO over Mexico in warm and cold seasons has previously been investigated. The El Niño was found to favour wet conditions during summers of the PDO cold phase and during winters of the PDO warm phase throughout Mexico. During winter in Mesoamerica, the PDO forcing was more prominent when in association with El Niño phases [191]. When ENSO and PDO are in phase (out of phase), the sea level pressure anomalies over the Caribbean are enhanced (weakened or cancelled). This affects the CLLJ anomalies in direction and intensity, and changes the spatial distribution of precipitation [193].

The AMO is a natural mode of variability in the North Atlantic on multi-decadal time scales [194,195]. In general, the positive AMO phase favours tropical convective activity over the Caribbean, bringing much of the rainfall during the boreal summer wet season [196]. Wetter (drier) conditions over Central America during summer (winter) were modulated by the AMO [197]. The AMO 
is also important in terms of influencing Atlantic TC activity at decadal time scales [198]. The impact of the AMO on seasonal TC activity manifests itself through the AMM as the former can activate the AMM at decadal time scales [182]. The AMO is also important for the low-frequency variability of precipitation as it modulates the distribution of moisture and extreme rainfall events. A direct relationship between droughts and the variations of AMO and PDO and the rainy (dry) periods in the north (south) of Mexico has also been identified [199]. Positive (negative) AMO and negative (positive) PDO were related to wet (dry) conditions in north (south) Mexico.

\section{Climate Change in the Regional Context}

\subsection{Past Climatic Changes}

Past climatic changes associated with external forcing (i.e., orbital forcing, plate tectonics, and solar activity), have caused major changes in temperature and dry-wet conditions at geological time scales [200]. Paleoclimatic records (i.e., sediments, corals, and spelaeothems) have enabled the evaluation of past climate in the region, where the findings have revealed the relevance of ITCZ for changes in rainfall. The Central American Seaway (CAS) closure is a relevant source of regional climatic changes associated with deep ocean circulation variations [201,202]. The past ITCZ position has been a major force in shaping regional rainfall, with a southern ITCZ in periods of cooler SSTs as those during the Younger Dryas (YD) and the Little Ice Age (LIA), and a northern ITCZ during warmer periods [203]. The cooling in the Caribbean during the LIA was a result of the reduction of the AWP and anomalous atmospheric circulation patterns [204]. According to paleosalinity records, a relevant feedback between ITCZ positioning and variations in the deep ocean circulation suggests that ITCZ movements were crucial in creating significant rainfall differences between the Pacific and Caribbean [205]. Changes in the ITCZ position may have modulated regional moisture transport with a certain degree of similarity, as it occurs in the present climate. Past inter-basin moisture transport analysis confirms that the increase in moisture transport across Central America is consistent with northern shifts of the ITCZ at millennial scales [206]. Anomalously enhanced rainfall patterns correspond to intensified exports of moisture northward that may have contributed to regions as far as Greenland during the late Quaternary [207]. Paleoclimatic studies are in agreement with major changes in the regional hydroclimate, finding that despite the action of external forcings, major changes were driven by drastic SST changes or inter-ocean temperature gradients [208]. The reconstruction of the frequency and magnitude of past rainfall variability for Central America may be attributed to an increase in precipitation in Belize during the mid-Holocene to the expansion of the NASH and the strengthening of the CLLJ [209]. The Terminal Classic Drought had an important impact on southern Costa Rica during the late Holocene [210]. The most relevant findings of past SST reconstructions indicate that the ENSO is a modulator of rainfall conditions, often measured in terms of coral reef shutdown [211]. A relationship between major dry events during the Common Era and El Niño conditions is associated with southern shifts in the ITCZ [212]. Past climate reconstructions show the region experienced drastic changes, inducing wet-dry contrasts. Such changes were related to societal behaviour, allowing for a better understanding of the past impacts of climate on regional livelihoods [213].

\subsection{The Anthropocene}

Anthropogenic socio-environmental changes and degradation (e.g., global warming, sea-level rise, erosion, and social conflicts) are part of global climate change. The establishment of the Anthropocene marks a fundamental change in the relationship between humans and the Earth's climate system [214] through the modification of carbon input in the atmosphere [215]. The load of greenhouse gases (e.g., $\mathrm{CO}_{2}$ and $\mathrm{CH}_{4}$ ) into the atmosphere has accelerated global warming [216], triggering consequential environmental changes [217]. Climate sensitivity has increased as a result of the increase in $\mathrm{CO}_{2}$ concentrations [218]. Therefore, the intensification of the hydrological cycle has increased the frequency and intensity of extreme events, from which drought propagation 
is a major concern [219]. The contribution of anthropogenic warming to drought severity was noticeable during the Pan-Caribbean drought in 2013-2016, where a key forcing was the effects of temperature on potential evapotranspiration [220]. Evidence of anthropogenic influence is also observed in the tropical forests of Central America via human influence and impacts through hunting, fire, and agriculture [221]. Deforestation and land use changes account for most of the anthropogenic-related changes in this region, as massive forest clearings took place prior to the recovery of forested areas. This is despite the region currently being recognised instituting decades of public policies oriented to conservation [222]. Knowledge of the environmental changes induced by human activity inform conservation, management, and adaptation [223]. It also opens up debates on the responsibility of mankind for the natural environment [224], and the importance of sustainable development. Despite the well-known inequality between greenhouse gas contributors and areas experiencing the most severe impacts of climate change [225], anthropogenic climate change is global, and research is key for mitigation.

\subsubsection{Observed Climate Change}

Regional long-term trends are significant mostly for temperature [226], whilst the significance for rainfall has limitations for surface temperature trends between 1950 and 2019 based on the Climate Research Unit (CRU) database and ERA-5, as shown in Figure 8. Changes between 0.15 and $0.45^{\circ} \mathrm{C}$ per decade have been identified for northern Central America and north-western Mexico. For the latter, the signal points to general warming as well as seasonal differences, with summer becoming warmer [227]. Similar to Central America, the analysis of extremes has shown an intensification of heatwave events [228]. For the Caribbean, an increase in the minimum temperatures and a larger frequency of warmer days and nights has been reported [229]. The Caribbean has been warming in the last four decades. Even when smaller warming signals were detected in the western Caribbean (the 1950s) and the southern Caribbean (the 1940s and the 1960s), sustained warming was evident after the 1980s [230,231]. A multiscale approach showed a significant increasing trend in the length of the MSD in the Pacific coast of Nicaragua, Honduras, and Guatemala, with increases estimated to be nearly 20 days per decade [232].
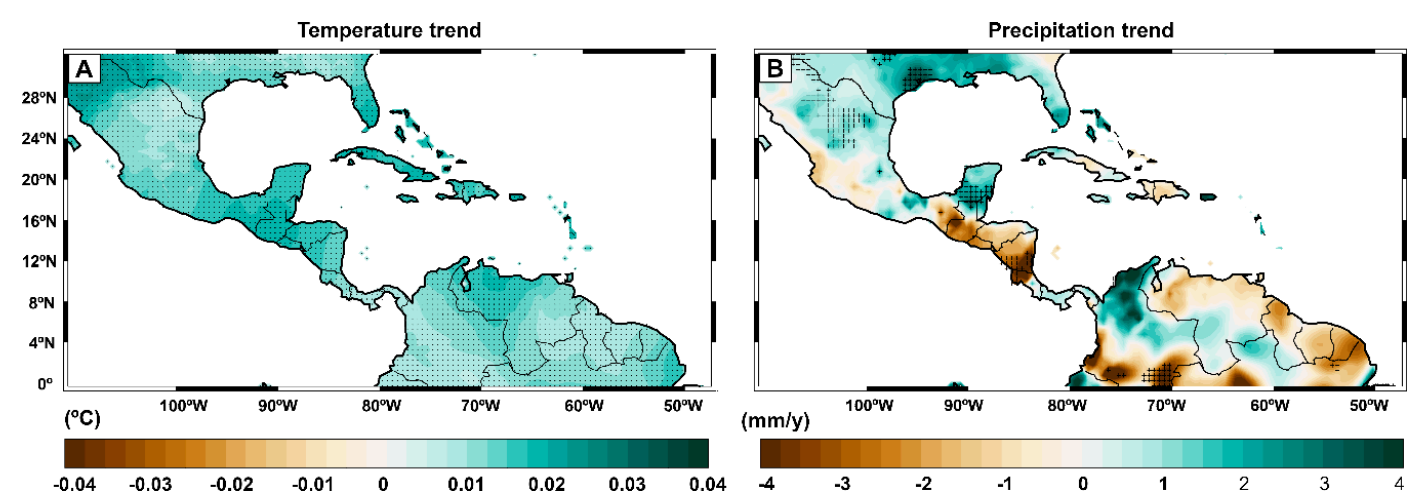

Figure 8. Long-term trends between 1950 and 2019 for (A) temperature based on the Climatic Research Unit gridded Time Series (CRU TS) v4.04, and (B) rainfall based on ERA-5. Dots represent statistically significant trends at $p<0.05$.

Drying may be one of the key observed climate change impacts for Mexico [233], with increasing trends in the number of consecutive dry days and decreasing trends in rainfall intensity for central Mexico. In contrast, increasing trends for rainfall were detected for north-western Mexico, although this may be attributed in most cases by the PDO [234]. Tree ring analysis has shown a decreasing rainfall trend for the 1970-2007 period [235]. The Caribbean exhibits little to no significant rainfall trends with relatively small positive trends for annual rainfall as well as daily intensity and the number of consecutive dry days [229]. Figure $8 \mathrm{~B}$ shows a low level of statistical significance for rainfall trends 
and the contrasting trends of increases (decreases) for the Yucatan Peninsula and northern Mexico (northern Central America and the Caribbean).

\subsubsection{Future Climate Scenarios}

Long-term climate simulations for the 21st century based on the Special Report on Emissions Scenarios (SRES) and Representative Concentration Pathways (RCPs) global scenarios are available as part of different global initiatives [236,237]. These simulations have allowed the subsequent utilisation of global climate models to project future climate. In addition to the use of projections from the Coupled Model Inter-Comparison Project (CMIP)3 [238], CMIP5 [239], and CMIP6 [240], statistical [43,241] and dynamic [242-244] downscaling techniques have been used to provide enhanced spatial scale representation of smaller areas. The implementation of these techniques is fundamental in representing the small islands of the Caribbean and better resolving complex regional topography to extract higher-quality information for the landmass [245]. The performance of downscaling is critically dependent on the driving global climate model [246]; as such, there needs to be careful interpretation of model outputs. Most CMIP3 models suggest a decrease in precipitation over the Caribbean under the SRES A2 scenario, while the CMIP3 ensemble median projections for the 2080s (relative to 1970-1989 mean) point to a drying of 30-40\% in the western Caribbean and 20-30\% in the eastern Caribbean [246]. Similar results have been reported in Reference [247] with drier conditions projected in SRES A2 and B2 scenarios for the Caribbean for 2071-2099 due to an increase in consecutive dry days. Independent assessments of changes to precipitation in Central America between 2021 and 2050 (with respect to the baseline 1961-1990), based on the RCP 4.5, suggest a rainfall decrease and the strengthening of the MSD in agreement with observed changes in recent decades. Rainfall projections show a contrasting decrease (increase) in northern (southern) Central America [248].

Under the warmest SRES A2, there is a consensus among simulations suggesting that Central America may experience significant drying during the summer months by the end of the 21st century, relative to the first half of the 20th century [249]. A higher frequency of extended dry seasons over the south of Mexico and Central America is projected based on the RCP8 for the end of the century. This drier scenario is associated with a larger warming of the Tropical North-Eastern Pacific (TNP) compared to the TNA [241]. The projected persistence of a strong CLLJ beyond July and November was linked to the perpetuation of a dry pattern in the Caribbean. The CMIP3 projections suggest a decrease in rainfall for most of Central America and Northern Venezuela, during all seasons, by the end of the 21st century [250]. Such reductions in precipitation may result in the amplification of runoff changes in Central America, experiencing reductions from 10\% to 30\% in the A1B scenario by the end of the century [43]. Similar to Panama, the authors of Reference [251] identified that rainfall decreases may be followed by a runoff reduction, whereas there may be an absence of significant changes in the projected evaporation. Projected rainfall reduction for Central America and northern South America is accompanied by warming as well as an increase in evaporation and reduction in soil moisture [250]. The SRES A1B scenario suggests a $1.8^{\circ} \mathrm{C}$ median annual increase in surface temperature in the Caribbean Sea by the end of the 21st century compared to the 1980-1999 baseline. In southern Central America, the projected temperature may increase between 1.6 and $2.0^{\circ} \mathrm{C}$ [248], and warming may be accompanied by a $21.42 \mathrm{~cm}$ of sea level rise by 2040 on the Caribbean and Central American coast under the RCP6.0 [252]. The CMIP5 indicates a temperature increase of 1.5 and $2{ }^{\circ} \mathrm{C}$ accompanied by a rainfall decrease of $5 \%$ and $10 \%$ for the RCP4.5 and RCP8.5 for Mexico, respectively. This is alongside north-south contrasts for rainfall projections featuring an increase-decrease pattern [253].

To update the previous results, we employed monthly precipitation and temperature from four CMIP6 climate models (The Canadian Earth System Model version 5 (CanESM5), Community Earth System Model version 2 (CESM2), Centre National de Recherches Météorologiques - Coupled atmosphere ocean general circulation model of sixth generation (CNRM-CM6-1), and the Max Planck Institute Earth system model (MPI-ESM)) from the Scenario Model Intercomparison Project (SMIP) to obtain multi-model means for 2021-2050 and 2051-2100, and calculate anomalies with respect to 
the historical period (1980-2009) based on temperature from CRU TS v.4.04 and precipitation from the combined precipitation dataset of the Global Precipitation Climatology Project (GPCP) v.3.0 [254]. We focused on climate predictions driven by three different shared socio-economic pathways (SSPs) characterised by low, middle, and high forcing conditions (i.e., SSP1-2.6, SSP2-3.7, and SSP5-8.5, respectively). Figure 9 shows a similar pattern for temperature anomalies for the three SSPs between 2021 and 2050 with warming over most of the region and cooling in central and northern México. For the second half of the century (not shown), the warming pattern affected all regions under SSP3-7.0 and SSP5-8.5. The results for rainfall showed similar spatial anomaly patterns, with an overall rainfall decrease (increase) in Central America and southern Mexico (central Mexico) for 2021-2050 in the three scenarios. In contrast to the continent, rainfall in the Caribbean is featured by an east-west dipole of positive-negative rainfall anomalies. At the end of the century (not shown), the anomaly patterns reveal slight changes for the SSP1-2.6, with an increase in positive anomalies over the west of northern South America and the Pacific Ocean. The CMIP-6 scenarios suggest that there may be significant changes in rainfall across the ITCZ zone, with the regional LJJs likely playing a relevant role in changes to rainfall patterns.

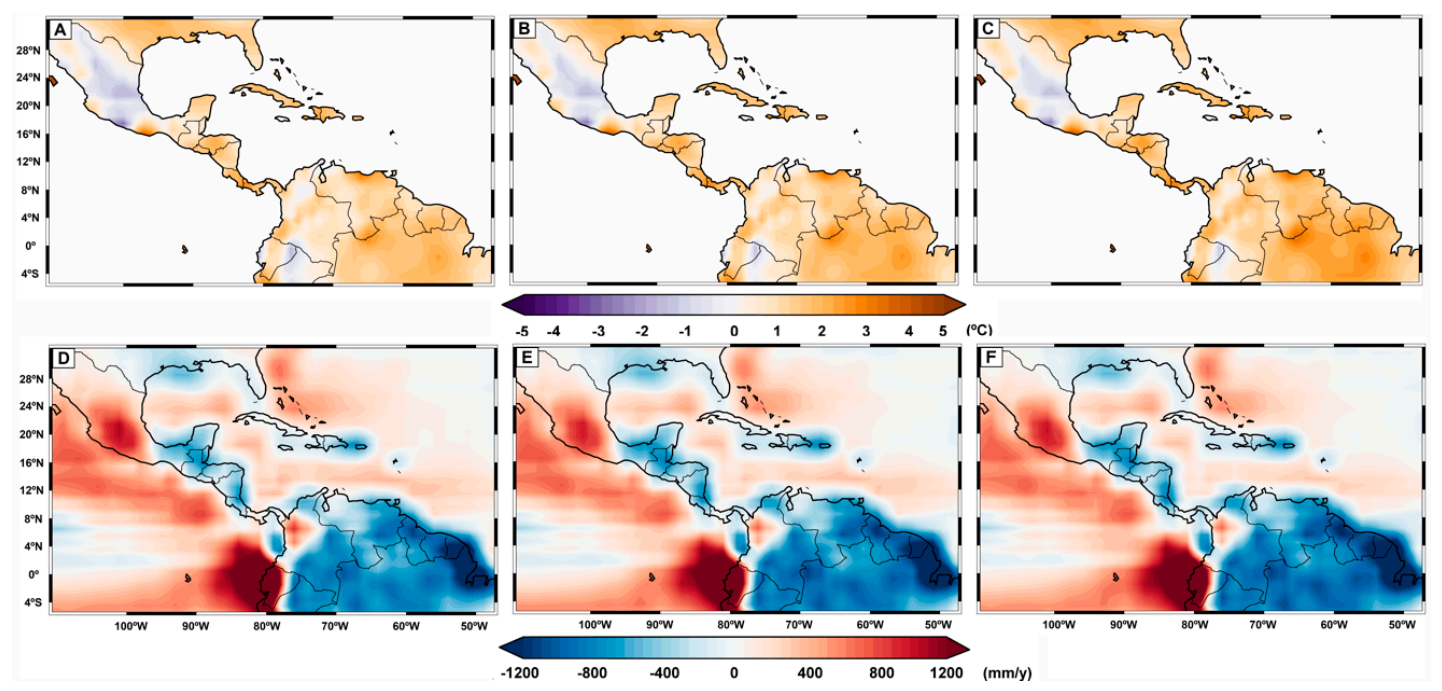

Figure 9. Surface temperature anomalies from multi-model mean (CanESM5, CESM2, CNRM-CM6-1, MPI-ESM) under the (A) SSP1-2.6, (B) SSP3-7.0, and (C) SSP5-8.5 for the 2021-2050 period, in reference to the baseline between 1980 and 2009 from the gridded CRU TS v.4.04 dataset and rainfall anomalies under the (D) SSP1-2.6, (E) SSP3-7.0, and (F) SSP5-8.5 for the 2021-2050 period, in reference to the baseline 1980-2009 from the Global Precipitation Climatology Project (GPCP) v.3.0 dataset.

\subsubsection{Projected Impacts of Climate Change}

Climate change poses a series of challenges to Central America, Mexico, and the Caribbean. Despite the region's low levels of greenhouse gas emissions, it is particularly vulnerable to the negative impacts of climate change. The projected impacts on water availability, agriculture, ecological disruptions, infrastructure risk from extreme weather events (severity and frequency), and diseases are expected to be unequal among regions and socioeconomic groups [255]. This is because intra-regional variations in climate are crucial in determining the vulnerability for this region, warranting the need for mitigation and adaptation plans [256]. Rainfall projections estimate that future water availability is likely to decrease. With limited water resources and an increase in the demand for consumption and production (e.g., agriculture), the situation appears complex for areas where a rainfall decrease is projected to exacerbate. Climate projections estimate an $82 \%$ reduction in the average regional water availability under the B2 scenario and a 90\% reduction under the A2 scenario by the year 2100 [257]. A projected increase in droughts in the Caribbean [258] is also expected to be associated with water availability disruptions. The results indicate that climate change has a greater negative impact on water availability 
and food security compared to the impact of climate variability. With a decline in average long-term precipitation, a severe decrease in groundwater storage occurs [259], increasing future pressures on water resources. Other projected impacts of climate change include an increase in the frequency of heatwaves [260], rainforest biomass changes [261], and ocean acidification, which will impact mangrove forests, corals, and cause a disruption in the trophic chain [262].

\section{Conclusions}

This study presented a comprehensive review of climate in the IAS, the predominant climate features, the influence of variability modes, and past and future climate. The IAS is prone to impacts by hydro-meteorological hazards, from droughts to hurricanes, and is particularly vulnerable to climate change and variability impacts. To date, research efforts have made significant progress in understanding the current climate and its variability. The scale of the region and the large elements that interact to build the regional climate represent a complex challenge, as the multi-scale connectivity is not fully understood. Over ocean and land, we understand very little regarding the boundary layer and how feedbacks through this interface account for the energy transfer between the surface and atmosphere. Furthermore, there continues to be a need to understand how SST changes map onto variations in the atmosphere to reconcile knowledge of past climate with future scenarios. Lessons from the analysis of currently available datasets shed light on the fact that greater commitment is needed to leverage long-term surface monitoring. This is because observational evidence is key for variability and change assessments, and for validating satellite-derived products alongside climate models. One of the major risks the region may experience is related to the increases in extreme events. However, meteorological records do not possess the frequency required to properly identify whether intense rainfall events have been increasing. In coastal regions, there is a lack of sea level monitoring, making it difficult to validate satellite estimation.

Climate change is often analysed in the region from a large-scale perspective. As such, analysis of surface feedback is scarce in comparison to larger-scale studies. In a region featuring sharp contrasts within a few kilometres, understanding changes at the local scale is fundamental. Firstly, it is important as a means to address the knowledge gaps in terms of the local components of the hydrological cycle. Secondly, because the local scale is required to properly represent the climate system for regions such as the IAS. Without the local scale, there may only be limited improvements to surface coupling models, and this indicates that further advances in modelling are constrained by the surface. Climate change impacts in the region are undeniable, and the region has decent and sufficient evidence to describe these impacts. However, this information does not necessarily reach the productive sectors, and public policy oriented to mitigate the impacts of climate change often overlooks evaluation metrics. Under these circumstances, actions taken to reduce the impact of climate change cannot be measured; as a result, further improvements are limited. A better communication between academia and various groups in society is required to ensure that the knowledge generated is properly transferred. It is crucial to leverage the use of climatic data to include quantitative indicators to evaluate the capabilities of adaptation and mitigation plans. Moreover, policymaking should focus on the most vulnerable areas, where the socioeconomic activities are largely constrained by water availability and the population is highly exposed.

Author Contributions: Conceptualisation was developed by A.M.D.-Q., L.G., and P.O.; data preparation and figures were carried out by R.S. and A.M.D.-Q.; writing, review, and editing by A.M.D.-Q., L.G., P.O., and R.S. All authors have read and agreed to the published version of the manuscript.

Funding: This work was completed with support from the IAEA RC-23507 (CRP-F31006) grant and the LAGRIMA project (grant no. RTI2018-095772-B-I00) funded by the Ministerio de Ciencia, Innovación y Universidades, Spain. Additional support for the authors was provided by Xunta de Galicia under the project Programa de Consolidación e Estructuración de Unidades de Investigación Competitivas (Grupos de Referencia Competitiva) (no. ED431C 2017/64-GRC) and PAPIIT IN116120 project. 
Acknowledgments: The authors acknowledge data availability of the CMIP6, CRU, ERA-5, GPCP, and HURDAT datasets. A.M. acknowledges IAEA CRP-F31006, R.S. acknowledges the post-doctoral fellowship by the Xunta de Galicia (grant no. ED481B 2019/070). P.O. was also supported by the project PAPIIT IN116120.

Conflicts of Interest: The authors declare no conflict of interest.

\section{References}

1. Wang, B.; Ding, Q. Changes in global monsoon precipitation over the past 56 years. Geophys. Res. Lett. 2006, 33, 06711. [CrossRef]

2. Wang, B.; Li, J.; Cane, M.A.; Liu, J.; Webster, P.J.; Xiang, B.; Kim, H.-M.; Cao, J.; Ha, K.-J. Toward Predicting Changes in the Land Monsoon Rainfall a Decade in Advance. J. Clim. 2018, 31, 2699-2714. [CrossRef]

3. Higgins, R.W.; Gochis, D. Synthesis of Results from the North American Monsoon Experiment (NAME) Process Study. J. Clim. 2007, 20, 1601-1607. [CrossRef]

4. Dominguez, F.; Miguez-Macho, G.; Hu, H. WRF with Water Vapor Tracers: A Study of Moisture Sources for the North American Monsoon. J. Hydrometeorol. 2016, 17, 1915-1927. [CrossRef]

5. Ramage, C.S. Monsoon Meteorology; International Geo-Physics Series; Academic Press: Cambridge, MA, USA, 1971; Volume 15.

6. Wang, B.; Jin, C.; Liu, J. Understanding Future Change of Global Monsoons Projected by CMIP6 Models. J. Clim. 2020, 33, 6471-6489. [CrossRef]

7. Amador, J.A.; Rivera, E.R.; Durán-Quesada, A.M.; Mora, G.; Sáenz, F.; Calderon, B. The easternmost tropical Pacific. Part I: A climate review. Rev. De Biol. Trop. 2016, 64, 1. [CrossRef]

8. Misra, V.; Mishra, A.; Li, H. The sensitivity of the regional coupled ocean-atmosphere simulations over the Intra-Americas seas to the prescribed bathymetry. Dyn. Atmos. Ocean. 2016, 76, 29-51. [CrossRef]

9. Wang, C.; Enfield, D. The Tropical Western Hemisphere Warm Pool. Geophys. Res. Lett. 2001, 28, 1635-1638. [CrossRef]

10. Chang, Y.L.; Oey, L.Y. Coupled response of the trade wind, SST gradient, and SST in the Caribbean Sea, and the potential impact on Loop Current's interannual variability. J. Phys. Oceanogr. 2013, 43, 1325-1344. [CrossRef]

11. Amador, J.A. The intra-Americas sea low-level jet: Overview and future research. Ann. N. Y. Acad. Sci. 2008, 1146, 153-188. [CrossRef]

12. Poveda, G.; MesaiD, O.J. On the existence of Lloró (the rainiest locality on Earth): Enhanced ocean-land-atmosphere interaction by a low-level jet. Geophys. Res. Lett. 2000, 27, 1675-1678. [CrossRef]

13. Cook, K.H.; Vizy, E.K. Hydrodynamics of the Caribbean Low-Level Jet and Its Relationship to Precipitation. J. Clim. 2010, 23, 1477-1494. [CrossRef]

14. Hidalgo, H.G.; Durán-Quesada, A.M.; Amador, J.A.; Alfaro, E.J. The caribbean low-level jet, the inter-tropical convergence zone and precipitation patterns in the intra-americas sea: A proposed dynamical mechanism. Geogr. Ann. Ser. Aphys. Geogr. 2015, 97, 41-59. [CrossRef]

15. Sierra, J.; Arias, P.A.; Vieria-Agudelo, S.C.; Agudelo, J. How well do CMIP5 models simulate the low-level jet in western Colombia? Clim. Dyn. 2017, 51, 2247-2265. [CrossRef]

16. Magaña, V.; Amador, J.A.; Medina, S. The Midsummer Drought over Mexico and Central America. J. Clim. 1999, 12, 1577-1588. [CrossRef]

17. Janowiak, J.E.; Arkin, P.A.; Xie, P.; Morrissey, M.L.; LeGates, D.R. An Examination of the East Pacific ITCZ Rainfall Distribution. J. Clim. 1995, 8, 2810-2823. [CrossRef]

18. Franco-Díaz, A.; Klingaman, N.P.; Vidale, P.L.; Guo, L.; Demory, M.-E. The contribution of tropical cyclones to the atmospheric branch of Middle America's hydrological cycle using observed and reanalysis tracks. Clim. Dyn. 2019, 53, 6145-6158. [CrossRef]

19. Dominguez, C.; Done, J.M.; Bruyère, C.L. Easterly wave contributions to seasonal rainfall over the tropical Americas in observations and a regional climate model. Clim. Dyn. 2019, 54, 191-209. [CrossRef]

20. Machado, L.A.T.; Rossow, W.B.; Guedes, R.L.; Walker, A.W. Life Cycle Variations of Mesoscale Convective Systems over the Americas. Mon. Weather. Rev. 1998, 126, 1630-1654. [CrossRef]

21. Grabowski, R. Political legitimacy and economic development: The role of agriculture in Costa Rica. Prog. Dev. Stud. 2016, 16, 361-366. [CrossRef] 
22. Peguero, F.; Zapata, S.; Sandoval, L. Agricultural Production of Central America and the Caribbean: Challenges and Opportunities. Agric. Appl. Econ. Assoc. 2019, 34. [CrossRef]

23. Loyola, C.E.; Dole, J.M.; Dunning, R. South and Central America Cut Flower Production and Postharvest Survey. HortTechnology 2019, 29, 898-905. [CrossRef]

24. Smith, K. Conservation and Caffeine: The History of Coffee Tourism and Sustainability in Costa Rica. Undergraduate Thesis, Southern Illinois University, Carbondale, IL, USA, 2019.

25. Dooley, K.; Dobbins, C.; Edgar, L.; Borges, B.; Jones, S.; Hernandez, J.; Birnbaum, A. A cross case synthesis of the social and economic development of three Guatemalan coffee cooperatives. Adv. Agric. Dev. 2020, 1, 1-13. [CrossRef]

26. Rojas-Romagosa, H.; Guevara, P. Economic Impact for Central America, Panama and the Dominican Republic (CAPDR) of Changes in US Trade Policy, Increased Regional Integration and New Trade Agreements; GTAP: West Lafayette, IN, USA, 2017.

27. Chen, C.-F.; Son, N.-T.; Chen, C.-R.; Chiang, S.; Chang, L.; Valdez, M.C. Drought monitoring in cultivated areas of Central America using multi-temporal MODIS data. Geomat. Nat. Hazards Risk 2016, 8, $402-417$. [CrossRef]

28. Ayala, J.H.; Heslar, M. Examining the spatiotemporal characteristics of droughts in the Caribbean using the standardized precipitation index (SPI). Clim. Res. 2019, 78, 103-116. [CrossRef]

29. Avelino, J.; Cristancho, M.A.; Georgiou, S.; Imbach, P.; Aguilar, L.; Bornemann, G.; Laderach, P.; Anzueto, F.; Hruska, A.J.; Morales, C. The coffee rust crises in Colombia and Central America (2008-2013): Impacts, plausible causes and proposed solutions. Food Secur. 2015, 7, 303-321. [CrossRef]

30. Bacon, C.M.; Sundstrom, W.A.; Stewart, I.T.; Beezer, D. Vulnerability to Cumulative Hazards: Coping with the Coffee Leaf Rust Outbreak, Drought, and Food Insecurity in Nicaragua. World Dev. 2017, 93, 136-152. [CrossRef]

31. Alpízar, F.; Saborío-Rodríguez, M.; Martínez-Rodríguez, M.R.; Viguera, B.; Vignola, R.; Capitán, T.; Harvey, C.A. Determinants of food insecurity among smallholder farmer households in Central America: Recurrent versus extreme weather-driven events. Reg. Environ. Chang. 2020, 20. [CrossRef]

32. Johnson, A. Achieving 100\% Reliance on Renewable Energy for Electricity Generation in Central America; GENI: San Diego, CA, USA, 2012.

33. Meza, C. A review on the Central America electrical energy scenario. Renew. Sustain. Energy Rev. 2014, 33, 566-577. [CrossRef]

34. Yépez-García, R.; Johnson, T.M.; Andrés, L.A. Meeting the Electricity Supply/Demand Balance in Latin America $\mathcal{E}$ the Caribbean; The World Bank: Washington, DC, USA, 2010.

35. Instituto Mexicano de Tecnología del Agua (IMTA). Bases Para un Centro Mexicano en Innovación de Energía Hidroeléctrica. 1era Parte: Infraestructura Hidroeléctrica Actual; IMTA: Jiutepec, Mexican, 2017; ISBN 978-607-9368-93-7.

36. NgiD, J.Y.; Turner, S.W.; Galelli, S. Influence of El Niño Southern Oscillation on global hydropower production. Environ. Res. Lett. 2017, 12, 034010. [CrossRef]

37. Barlow, M. Access to Clean Water is Most Violated Human Right. The Guardian. 21 July 2010. Available online: http://westmidwest.nonprofitsoapbox.com/storage/documents/Justice/Documents/ Common_Dreamshuman_right_to_clean_water.pdf (accessed on 9 September 2020).

38. Litter, M.I.; Morgada, M.E.; Bundschuh, J. Possible treatments for arsenic removal in Latin American waters for human consumption. Environ. Pollut. 2010, 158, 1105-1118. [CrossRef] [PubMed]

39. Soares, L.C.R.; Griesinger, M.O.; Dachs, J.N.W.; Bittner, M.A.; Tavares, S. Inequities in access to and use of drinking water services in Latin America and the Caribbean. Rev. Panam. De Salud Pública 2002, 11, 386-396. [CrossRef] [PubMed]

40. Kuzdas, C.; Warner, B.; Wiek, A.; Yglesias, M.; Vignola, R.; Ramírez-Cover, A. Identifying the potential of governance regimes to aggravate or mitigate local water conflicts in regions threatened by climate change. Local Environ. 2015, 21, 1387-1408. [CrossRef]

41. Esquivel-Hernández, G.; Sánchez-Murillo, R.; Birkel, C.; Boll, J. Climate and Water Conflicts Coevolution from Tropical Development and Hydro-Climatic Perspectives: A Case Study of Costa Rica. Jawra J. Am. Water Resour. Assoc. 2017, 54, 451-470. [CrossRef] 
42. Reyer, C.P.; Adams, S.; Albrecht, T.; Baarsch, F.; Boit, A.; Trujillo, N.C.; Cartsburg, M.; Coumou, D.; Eden, A.; Fernandes, E.; et al. Climate change impacts in Latin America and the Caribbean and their implications for development. Reg. Environ. Chang. 2015, 17, 1601-1621. [CrossRef]

43. Hidalgo, H.G.; Amador, J.A.; Alfaro, E.J.; Quesada, B. Hydrological climate change projections for Central America. J. Hydrol. 2013, 495, 94-112. [CrossRef]

44. Taylor, M.A.; Whyte, F.S.; Stephenson, T.S.; Campbell, J.D. Why dry? Investigating the future evolution of the Caribbean Low Level Jet to explain projected Caribbean drying. Int. J. Clim. 2012, 33, 784-792. [CrossRef]

45. Scholze, M.; Knorr, W.; Arnell, N.W.; Prentice, I.C. A climate-change risk analysis for world ecosystems. Proc. Natl. Acad. Sci. USA 2006, 103, 13116-13120. [CrossRef]

46. Aleixo, I.; Norris, D.; Hemerik, L.; Barbosa, A.; Prata, E.M.B.; Costa, F.; Poorter, L. Amazonian rainforest tree mortality driven by climate and functional traits. Nat. Clim. Chang. 2019, 9, 384-388. [CrossRef]

47. Mason-Romo, E.D.; Ceballos, G.; Lima, M.; Martínez-Yrízar, A.; Jaramillo, V.J.; Maass, M. Long-term population dynamics of small mammals in tropical dry forests, effects of unusual climate events, and implications for management and conservation. For. Ecol. Manag. 2018, 426, 123-133. [CrossRef]

48. Stan, K.; Sanchez-Azofeifa, A. Tropical Dry Forest Diversity, Climatic Response, and Resilience in a Changing Climate. Forests 2019, 10, 443. [CrossRef]

49. Wu, G.; Liu, Y. Summertime quadruplet heating pattern in the subtropics and the associated atmospheric circulation. Geophys. Res. Lett. 2003, 30. [CrossRef]

50. Davis, R.E.; Hayden, B.P.; Gay, D.A.; Phillips, W.L.; Jones, G.V. The North Atlantic Subtropical Anticyclone. J. Clim. 1997, 10, 728-744. [CrossRef]

51. Sahsamanoglou, H.S. A contribution to the study of action centres in the North Atlantic. Int. J. Clim. 1990, 10, 247-261. [CrossRef]

52. Li, W.; Li, L.; Fu, R.; Deng, Y.; Wang, H. Changes to the North Atlantic Subtropical High and Its Role in the Intensification of Summer Rainfall Variability in the Southeastern United States. J. Clim. 2011, 24, 1499-1506. [CrossRef]

53. Diem, J.E. Synoptic-Scale Controls of Summer Precipitation in the Southeastern United States. J. Clim. 2006, 19, 613-621. [CrossRef]

54. Wei, W.; Li, W.; Deng, Y.; Yang, S.; Jiang, J.H.; Huang, L.; Liu, W.T. Dynamical and thermodynamical coupling between the North Atlantic subtropical high and the marine boundary layer clouds in boreal summer. Clim. Dyn. 2017, 50, 2457-2469. [CrossRef]

55. Small, R.J.O.; De Szoeke, S.P.; Xie, S.-P. The Central American Midsummer Drought: Regional Aspects and Large-Scale Forcing. J. Clim. 2007, 20, 4853-4873. [CrossRef]

56. Li, L.; Li, W.; Kushnir, Y. Variation of the North Atlantic subtropical high western ridge and its implication to Southeastern US summer precipitation. Clim. Dyn. 2011, 39, 1401-1412. [CrossRef]

57. Sha, F.; Qi, L.; Yun-Fei, F. Precipitation under Subtropical High Conditions: Evidence and Implications. Atmos. Ocean. Sci. Lett. 2009, 2, 244-249. [CrossRef]

58. Li, W.; Li, L.; Ting, M.; Liu, Y. Intensification of Northern Hemisphere subtropical highs in a warming climate. Nat. Geosci. 2012, 5, 830-834. [CrossRef]

59. Song, F.; Leung, L.R.; Lu, J.; Dong, L. Seasonally dependent responses of subtropical highs and tropical rainfall to anthropogenic warming. Nat. Clim. Chang. 2018, 8, 787-792. [CrossRef]

60. Li, L.; Li, W.; Deng, Y. Summer rainfall variability over the Southeastern United States and its intensification in the 21st century as assessed by CMIP5 models. J. Geophys. Res. Atmos. 2013, 118, 340-354. [CrossRef]

61. Li, W.; Zou, T.; Li, L.; Deng, Y.; Sun, V.T.; Zhang, Q.; Layton, J.B.; Setoguchi, S. Impacts of the North Atlantic subtropical high on interannual variation of summertime heat stress over the conterminous United States. Clim. Dyn. 2019, 53, 3345-3359. [CrossRef]

62. Hadley, G. VI. Concerning the cause of the general trade-winds. Philos. Trans. R. Soc. Lond. 1735, 39, 58-62. [CrossRef]

63. Webster, P.J. The Elementary Hadley Circulation. In Advances in Global Change Research; Springer Science and Business Media LLC.: Berlin, Germany, 2004; Volume 21, pp. 9-60.

64. Lindzen, R.S.; Nigam, S. On the Role of Sea Surface Temperature Gradients in Forcing Low-Level Winds and Convergence in the Tropics. J. Atmos. Sci. 1987, 44, 2418-2436. [CrossRef]

65. Neelin, J.D. A simple model for surface stress and low-level flow in the tropical atmosphere driven by prescribed heating. Q. J. R. Meteorol. Soc. 1988, 114, 747-770. [CrossRef] 
66. Vimont, D.J.; Battisti, D.S.; Hirst, A.C. Footprinting: A seasonal connection between the tropics and mid-latitudes. Geophys. Res. Lett. 2001, 28, 3923-3926. [CrossRef]

67. Zhao, Y.; Di Lorenzo, E. The impacts of Extra-tropical ENSO Precursors on Tropical Pacific Decadal-scale Variability. Sci. Rep. 2020, 10,1-12. [CrossRef]

68. Renault, L.; McWilliams, J.C.; Masson, S. Satellite Observations of Imprint of Oceanic Current on Wind Stress by Air-Sea Coupling. Sci. Rep. 2017, 7, 17747. [CrossRef]

69. Wei, Y.; Pei, Y.; Kang, X. Assessing feedback of tropical instability wave-induced wind stress perturbations in the equatorial Pacific. Int. J. Clim. 2018, 39, 1634-1643. [CrossRef]

70. Hastenrath, S. Interannual Variability and Annual Cycle: Mechanisms of Circulation and Climate in the Tropical Atlantic Sector. Mon. Weather. Rev. 1984, 112, 1097-1107. [CrossRef]

71. Marshall, J.; Donohoe, A.; Ferreira, D.; McGee, D. The ocean's role in setting the mean position of the Inter-Tropical Convergence Zone. Clim. Dyn. 2014, 42, 1967-1979. [CrossRef]

72. SchneideriD, T.; Bischoff, T.; Haug, G.H. Migrations and dynamics of the intertropical convergence zone. Nature 2014, 513, 45-53. [CrossRef] [PubMed]

73. Xiang, B.; Zhao, M.; Ming, Y.; Yu, W.; Kang, S.M. Contrasting Impacts of Radiative Forcing in the Southern Ocean versus Southern Tropics on ITCZ Position and Energy Transport in One GFDL Climate Model. J. Clim. 2018, 31, 5609-5628. [CrossRef]

74. Nicholson, S.E. The ITCZ and the Seasonal Cycle over Equatorial Africa. Bull. Am. Meteorol. Soc. 2018, 99, 337-348. [CrossRef]

75. Wang, H.; Fu, R. The Influence of Amazon Rainfall on the Atlantic ITCZ through Convectively Coupled Kelvin Waves. J. Clim. 2007, 20, 1188-1201. [CrossRef]

76. Tomaziello, A.C.N.; Carvalho, L.M.V.; Gandu, A.W. Intraseasonal variability of the Atlantic Intertropical Convergence Zone during austral summer and winter. Clim. Dyn. 2015, 47, 1717-1733. [CrossRef]

77. Takahashi, K.; Battisti, D.S. Processes Controlling the Mean Tropical Pacific Precipitation Pattern. Part I: The Andes and the Eastern Pacific ITCZ. J. Clim. 2007, 20, 3434-3451. [CrossRef]

78. Durán-Quesada, A.M.; Gimeno, L.; Amador, J.A.; Nieto, R. Moisture sources for Central America: Identification of moisture sources using a Lagrangian analysis technique. J. Geophys. Res. Atmos. 2010, $16,115$.

79. Durán-Quesada, A.M.; Gimeno, L.; Amador, J. Role of moisture transport for Central American precipitation. Earth Syst. Dyn. 2017, 8, 147-161. [CrossRef]

80. Munnich, M.; Neelin, J.D. Seasonal influence of ENSO on the Atlantic ITCZ and equatorial South America. Geophys. Res. Lett. 2005, 32. [CrossRef]

81. Enfield, D.B.; Alfaro, E.J. The dependence of Caribbean rainfall on the interaction of the tropical Atlantic and Pacific Oceans. J. Clim. 1999, 12, 2093-2103. [CrossRef]

82. Enfield, D.; Lee, S.K. The Heat Balance of the Western Hemisphere Warm Pool. J. Clim. 2005, 18, $2662-2681$. [CrossRef]

83. Karnauskas, K.B.; Busalacchi, A.J. Mechanisms for the Interannual Variability of SST in the East Pacific Warm Pool. J. Clim. 2009, 22, 1375-1392. [CrossRef]

84. Fiedler, P.C. The annual cycle and biological effects of the Costa Rica Dome. Deep. Sea Res. Part I Oceanogr. Res. Pap. 2002, 49, 321-338. [CrossRef]

85. Misra, V.; Groenen, D.; Bhardwaj, A.; Mishra, A.; Bharadwaj, A. The warm pool variability of the tropical northeast Pacific. Int. J. Clim. 2016, 36, 4625-4637. [CrossRef]

86. Raymond, D.J.; Raga, G.B.; Bretherton, C.S.; Molinari, J.; López-Carrillo, C.; Fuchs, Ž. Convective Forcing in the Intertropical Convergence Zone of the Eastern Pacific. J. Atmos. Sci. 2003, 60, 2064-2082. [CrossRef]

87. Crosbie, E.; Serra, Y.L. Intraseasonal Modulation of Synoptic-Scale Disturbances and Tropical Cyclone Genesis in the Eastern North Pacific. J. Clim. 2014, 27, 5724-5745. [CrossRef]

88. Misra, V.; Chan, S.; Wu, R.; Chassignet, E. Air-sea interaction over the Atlantic warm pool in the NCEP CFS. Geophys. Res. Lett. 2009, 36. [CrossRef]

89. Sorí, R.; Drumond, A.; Nieto, R. Moisture contribution of the Atlantic Warm Pool to precipitation: A Lagrangian analysis. Front. Environ. Sci. 2015, 3. [CrossRef]

90. Ruiz-Barradas, A.; Nigam, S. Warm Season Rainfall Variability over the U.S. Great Plains in Observations, NCEP and ERA-40 Reanalyses, and NCAR and NASA Atmospheric Model Simulations. J. Clim. 2005, 18, 1808-1830. [CrossRef] 
91. Wang, C.; Lee, S.K.; Enfield, D. Climate Response to Anomalously Large and Small Atlantic Warm Pools during the Summer. J. Clim. 2008, 21, 2437-2450. [CrossRef]

92. Wang, C.; Enfield, D.; Lee, S.K.; Landsea, C.W. Influences of the Atlantic Warm Pool on Western Hemisphere Summer Rainfall and Atlantic Hurricanes. J. Clim. 2006, 19, 3011-3028. [CrossRef]

93. Li, X.; Xu, F.; Chen, H.; XIA, T.; TU, S.; Tianjin, B.N. Correlation analysis of the cycle process between the Western Pacific warm pool and ENSO during 1980-2016. J. Mar. Meteorol. 2017, 37, 85-94.

94. Whyte, F.S.; Taylor, M.A.; Stephenson, T.S.; Campbell, J.D. Features of the Caribbean low level jet. Int. J. Clim. 2007, 28, 119-128. [CrossRef]

95. Wang, C. Variability of the Caribbean Low-Level Jet and its relations to climate. Clim. Dyn. 2007, 29, 411-422. [CrossRef]

96. Jones, J.; Stephenson, T.S.; Taylor, M.A.; Campbell, J.D. Statistical downscaling of North Atlantic tropical cyclone frequency and the amplified role of the Caribbean low-level jet in a warmer climate. J. Geophys. Res. Atmos. 2016, 121, 3741-3758. [CrossRef]

97. Serra, Y.L.; Kiladis, G.N.; Hodges, K.I. Tracking and Mean Structure of Easterly Waves over the Intra-Americas Sea. J. Clim. 2010, 23, 4823-4840. [CrossRef]

98. Whitaker, J.W.; Maloney, E.D. Influence of the Madden-Julian Oscillation and Caribbean Low-Level Jet on East Pacific Easterly Wave Dynamics. J. Atmos. Sci. 2018, 75, 1121-1141. [CrossRef]

99. Poveda, G.; MesaiD, O.J. Feedbacks between Hydrological Processes in Tropical South America and Large-Scale Ocean-Atmospheric Phenomena. J. Clim. 1997, 10, 2690-2702. [CrossRef]

100. Sakamoto, M.S.; Ambrizzi, T.; Poveda, G.G. Rcio Moisture Sources and Life Cycle of Convective Systems over Western Colombia. Adv. Meteorol. 2012, 2011, 1-11. [CrossRef]

101. Arias, P.A.; Martínez, J.A.; Vieira, S.C. Moisture sources to the 2010-2012 anomalous wet season in northern South America. Clim. Dyn. 2015, 45, 2861-2884. [CrossRef]

102. Hoyos, I.; Dominguez, F.; Cañón-Barriga, J.; Martínez, J.A.; Nieto, R.; Gimeno, L.; Dirmeyer, P.A. Moisture origin and transport processes in Colombia, northern South America. Clim. Dyn. 2017, 50, 971-990. [CrossRef]

103. Gallego, D.; García-Herrera, R.; Gómez-Delgado, F.D.P.; Ordoñez-Perez, P.; Ribera, P. Tracking the moisture transport from the Pacific towards Central and northern South America since the late 19th century. Earth Syst. Dyn. 2019, 10, 319-331. [CrossRef]

104. Jaramillo, L.; Poveda, G.; Mejía, J.F. Mesoscale convective systems and other precipitation features over the tropical Americas and surrounding seas as seen by TRMM. Int. J. Clim. 2017, 37, 241-397. [CrossRef]

105. Yepes, J.; Poveda, G.; Mejía, J.F.; Moreno, L.; Rueda, C. CHOCO-JEX: A Research Experiment Focused on the Chocó Low-Level Jet over the Far Eastern Pacific and Western Colombia. Bull. Am. Meteorol. Soc. 2019, 100, 779-796. [CrossRef]

106. Poveda, G.; Álvarez, D.M.; Rueda, Ó.A. Hydro-climatic variability over the Andes of Colombia associated with ENSO: A review of climatic processes and their impact on one of the Earth's most important biodiversity hotspots. Clim. Dyn. 2010, 36, 2233-2249. [CrossRef]

107. Adams, D.K.; Comrie, A.C. The north American monsoon. Bull. Am. Meteorol. Soc. 1997, 78, $2197-2214$. [CrossRef]

108. Ordoñez-Peréz, P.; Nieto, R.; Gimeno, L.; Ribera, P.; Gallego, D.; Ochoa, C.; Quintanar, A.I. Climatological moisture sources for the Western North American Monsoon through a Lagrangian approach: Their influence on precipitation intensity. Earth Syst. Dyn. 2019, 10, 59-72. [CrossRef]

109. Vivoni, E.R.; Rodríguez, J.C.; Watts, C.J. On the spatiotemporal variability of soil moisture and evapotranspiration in a mountainous basin within the North American monsoon region. Water Resour. Res. 2010, 46. [CrossRef]

110. Vivoni, E.R.; Moreno, H.A.; Mascaro, G.; Rodríguez, J.C.; Watts, C.J.; Garatuza-Payan, J.; Scott, R.L. Observed relation between evapotranspiration and soil moisture in the North American monsoon region. Geophys. Res. Lett. 2008, 35. [CrossRef]

111. Barlow, M.; Nigam, S.; Berbery, E.H. Evolution of the North American Monsoon System. J. Clim. 1998, 11, 2238-2257. [CrossRef]

112. Berbery, E.H. Mesoscale Moisture Analysis of the North American Monsoon. J. Clim. 2001, 14, $121-137$. [CrossRef] 
113. Wright, W.E.; Long, A.; Comrie, A.C.; Leavitt, S.W.; Cavazos, T.; Eastoe, C. Monsoonal moisture sources revealed using temperature, precipitation, and precipitation stable isotope timeseries. Geophys. Res. Lett. 2001, 28, 787-790. [CrossRef]

114. Hu, H.; Dominguez, F. Evaluation of Oceanic and Terrestrial Sources of Moisture for the North American Monsoon Using Numerical Models and Precipitation Stable Isotopes. J. Hydrometeorol. 2015, 16, 19-35. [CrossRef]

115. Hastenrath, S.L. On General Circulation and Energy Budget in the Area of the Central American Seas. J. Atmos. Sci. 1966, 23, 694-711. [CrossRef]

116. Morales, J.S.; Arias, P.A.; Martínez, J.A. Role of Caribbean low-level jet and Choco jet in the transport of moisture patterns towards Central America. In Proceedings of the First International Electronic Conference on the Hydrological Cycle; MDPI: Basel, Switzerland, 2017; p. 4861.

117. Esquivel-Hernández, G.; Mosquera, G.M.; Sánchez-Murillo, R.; Quesada-Román, A.; Birkel, C.; Crespo, P.; Célleri, R.; Windhorst, D.; Breuer, L.; Boll, J. Moisture transport and seasonal variations in the stable isotopic composition of rainfall in Central American and Andean Páramo during El Niño conditions (2015-2016). Hydrol. Process. 2019, 33, 1802-1817. [CrossRef]

118. Durán-Quesada, A.M. Sources of Moisture for Central America and Transport Based on a Lagrangian Approach: Variability, Contributions to Precipitation and Transport Mechanisms. Unpublished. Ph.D. Thesis, University of Vigo, Vigo, Spain, 2012.

119. Sánchez-Murillo, R.; Durán-Quesada, A.M.; Birkel, C.; Esquivel-Hernández, G.; Boll, J. Tropical precipitation anomalies and d-excess evolution during El Niño 2014-16. Hydrol. Process. 2017, 31, 956-967. [CrossRef]

120. Taylor, M.A.; Stephenson, T.S.; Owino, A.; Chen, A.A.; Campbell, J.D. Tropical gradient influences on Caribbean rainfall. J. Geophys. Res. Space Phys. 2011, 116. [CrossRef]

121. Taylor, M.A.; Alfaro, E.J. Climate of Central America and the Caribbean. In Encyclopedia of World Climatology, Encyclopedia of Earth Sciences Series; Oliver, J., Ed.; Springer: Berlin/Heidelberg, Germany, 2005; pp. 183-189. [CrossRef]

122. Poveda, G.; MesaiD, O.J.; Salazar, L.F.; Arias, P.A.; Moreno, H.A.; Vieria-Agudelo, S.C.; Agudelo, P.A.; Toro, V.G.; Alvarez, J.F. The Diurnal Cycle of Precipitation in the Tropical Andes of Colombia. Mon. Weather. Rev. 2005, 133, 228-240. [CrossRef]

123. Magaña, V.; Caetano, E. Temporal evolution of summer convective activity over the Americas warm pools. Geophys. Res. Lett. 2005, 32. [CrossRef]

124. Curtis, S. Interannual variability of the bimodal distribution of summertime rainfall over Central America and tropical storm activity in the far-eastern Pacific. Clim. Res. 2002, 22, 141-146. [CrossRef]

125. Karnauskas, K.; Seager, R.; Giannini, A.; Busalacchi, A. A simple mechanism for the climatological midsummer drought along the Pacific coast of Central America. Atmósfera 2013, 26, 261-281. [CrossRef]

126. Gamble, D.W.; Parnell, D.B.; Curtis, S. Spatial variability of the Caribbean mid-summer drought and relation to north Atlantic high circulation. Int. J. Clim. 2008, 28, 343-350. [CrossRef]

127. Herrera, E.; Magaña, V.; Caetano, E. Air-sea interactions and dynamical processes associated with the midsummer drought. Int. J. Clim. 2014, 35, 1569-1578. [CrossRef]

128. Muñoz, E.; Busalacchi, A.J.; Nigam, S.; Ruiz-Barradas, A. Winter and Summer Structure of the Caribbean Low-Level Jet. J. Clim. 2008, 21, 1260-1276. [CrossRef]

129. Maldonado, T.; Rutgersson, A.; Alfaro, E.; Amador, J.; Claremar, B. Interannual variability of the midsummer drought in Central America and the connection with sea surface temperatures. Adv. Geosci. 2016, 42, 35-50. [CrossRef]

130. Perdigón-Morales, J.; Romero-Centeno, R.; Pérez, P.O.; Barrett, B.S. The midsummer drought in Mexico: Perspectives on duration and intensity from the CHIRPS precipitation database. Int. J. Clim. 2017, 38, 2174-2186. [CrossRef]

131. Zhao, Z.; Holbrook, N.J.; Oliver, E.C.J.; Ballestero, D.; Vargas-Hernandez, J.M. Characteristic atmospheric states during mid-summer droughts over Central America and Mexico. Clim. Dyn. 2020, 1-21. [CrossRef]

132. Wheeler, M.C.; Hendon, H.H. An all-season real-time multivariate MJO index: Development of an index for monitoring and prediction. Mon. Weather. Rev. 2004, 132, 1917-1932. [CrossRef]

133. Perdigón-Morales, J.; Romero-Centeno, R.; Barrett, B.S.; Ordoñez, P. Intraseasonal Variability of Summer Precipitation in Mexico: MJO Influence on the Midsummer Drought. J. Clim. 2019, 32, 2313-2327. [CrossRef] 
134. Pielke, R.A.; Rubiera, J.; Landsea, C.; Fernández, M.L.; Klein, R. Hurricane Vulnerability in Latin America and The Caribbean: Normalized Damage and Loss Potentials. Nat. Hazards Rev. 2003, 4, 101-114. [CrossRef]

135. Palmieri, S.; Teodonio, L.; Siani, A.-M.; Casale, G.R. Tropical storm impact in Central America. Meteorol. Appl. 2006, 13, 21-28. [CrossRef]

136. Rossi, E.; La Cerda, I.G.-D.; Oliver, C.; Kulakowski, D. Wind effects and regeneration in broadleaf and pine stands after hurricane Felix (2007) in Northern Nicaragua. For. Ecol. Manag. 2017, 400, 199-207. [CrossRef]

137. Beven, J.L. The 2016 Atlantic Hurricane Season: Matthew Leads an Above-Average Season. Weather 2017, 70, 28-35. [CrossRef]

138. Amador, J.A.; Magaña, V. The low-level jet and convective activity in the Caribbean. In Proceedings of the Reprints of the 24th Conference on Hurricanes and Tropical Meteorology, Fort Lauderdale, FL, USA, 29 May-2 June 2000; pp. 114-115.

139. Sánchez-Murillo, R.; Durán-Quesada, A.M.; Esquivel-Hernández, G.; Rojas-Cantillano, D.; Birkel, C.; Welsh, K.; Sánchez-Llull, M.; Alonso-Hernández, C.M.; Tetzlaff, D.; Soulsby, C.; et al. Deciphering key processes controlling rainfall isotopic variability during extreme tropical cyclones. Nat. Commun. 2019, 10, 4321-4331. [CrossRef]

140. Montgomery, M.T.; Farrell, B.F. Tropical Cyclone Formation. J. Atmos. Sci. 1993, 50, 285-310. [CrossRef]

141. Emanuel, K. Tropi Calcyclones. Annu. Rev. Earth Planet. Sci. 2003, 31, 75-104. [CrossRef]

142. Sobel, A.H.; Bretherton, C.S. Development of Synoptic-Scale Disturbances over the Summertime Tropical Northwest Pacific. J. Atmos. Sci. 1999, 56, 3106-3127. [CrossRef]

143. Goldenberg, S.B.; Shapiro, L.J. Physical Mechanisms for the Association of El Niño and West African Rainfall with Atlantic Major Hurricane Activity. J. Clim. 1996, 9, 1169-1187. [CrossRef]

144. Landsea, C.W. A climatology of intense (or major) Atlantic hurricanes. Mon. Weather Rev. 1993, 121, $1703-1713$. [CrossRef]

145. Blake, E.S.; Ethan, J.; Gibney, D.P.; Brown, M.M.; James, L.; Franklin, T.B. Tropical Cyclones of Eastern North Pacific Basin, 1949-2006, Historical Climatology Series 5-6; National Climatic Data Center: Asheville, NC, USA, 2009.

146. McAdie, C.J.; Landsea, C.J.; Neumann, E.S.; Blake, G.R. Tropical Cyclones of the North Atlantic Ocean, 1851-2006; Historical Climatology, Series Vol. 6-2; National Climatic Data Center: Asheville, NC, USA, 2009; 244p.

147. Houze, R.A., Jr. Mesoscale convective systems. Rev. Geophys. 2004, 42. [CrossRef]

148. Mapes, B.; Tulich, S.; Lin, J.; Zuidema, P. The mesoscale convection life cycle: Building block or prototype for large-scale tropical waves? Dyn. Atmos. Ocean. 2006, 42, 3-29. [CrossRef]

149. Zhang, S.; Parsons, D.B.; Wang, Y. Wave Disturbances and Their Role in the Maintenance, Structure, and Evolution of a Mesoscale Convection System. J. Atmos. Sci. 2019, 77, 51-77. [CrossRef]

150. Ocasio, K.M.N.; Evans, J.L.; Young, G.S. Tracking Mesoscale Convective Systems that are Potential Candidates for Tropical Cyclogenesis. Mon. Weather. Rev. 2020, 148, 655-669. [CrossRef]

151. Mohr, K.I.; Zipser, E.J. Mesoscale Convective Systems Defined by Their 85-GHz Ice Scattering Signature: Size and Intensity Comparison over Tropical Oceans and Continents. Mon. Weather. Rev. 1996, 124, 2417-2437. [CrossRef]

152. Nesbitt, S.W.; Zipser, E.J. The Diurnal Cycle of Rainfall and Convective Intensity according to Three Years of TRMM Measurements. J. Clim. 2003, 16, 1456-1475. [CrossRef]

153. Mapes, B.E.; Warner, T.T.; Xu, M.; Negri, A.J. Diurnal patterns of rainfall in northwestern South America. Part I: Observations and context. Mon. Weather Rev. 2003, 131, 799-812. [CrossRef]

154. Rydbeck, A.V.; Maloney, E.D.; Alaka, G.J. In Situ Initiation of East Pacific Easterly Waves in a Regional Model. J. Atmos. Sci. 2017, 74, 333-351. [CrossRef]

155. Nesbitt, S.W.; Cifelli, R.; Rutledge, S.A. Storm Morphology and Rainfall Characteristics of TRMM Precipitation Features. Mon. Weather Rev. 2006, 134, 2702-2721. [CrossRef]

156. Huaman, L.; Schumacher, C. Assessing the Vertical Latent Heating Structure of the East Pacific ITCZ Using the CloudSat CPR and TRMM PR. J. Clim. 2018, 31, 2563-2577. [CrossRef]

157. Rapp, A.D.; Peterson, A.G.; Frauenfeld, O.W.; Quiring, S.M.; Roark, E.B. Climatology of Storm Characteristics in Costa Rica using the TRMM Precipitation Radar. J. Hydrometeorol. 2014, 15, 2615-2633. [CrossRef]

158. Zuluaga, M.D.; Houze, R.A. Extreme Convection of the Near-Equatorial Americas, Africa, and Adjoining Oceans as seen by TRMM. Mon. Weather. Rev. 2015, 143, 298-316. [CrossRef] 
159. Schumacher, C.; Houze, R.A. Stratiform Rain in the Tropics as Seen by the TRMM Precipitation Radar. J. Clim. 2003, 16, 1739-1756. [CrossRef]

160. Zhang, C. Madden-Julian Oscillation. Rev. Geophys. 2005, 43. [CrossRef]

161. Zhang, C.; Gottschalck, J.; Maloney, E.D.; Moncrieff, M.W.; Vitart, F.; Waliser, D.; Wang, B.; Wheeler, M.C. Cracking the MJO nut. Geophys. Res. Lett. 2013, 40, 1223-1230. [CrossRef]

162. Barlow, M.; Salstein, D. Summertime influence of the Madden-Julian Oscillation on daily rainfall over Mexico and Central America. Geophys. Res. Lett. 2006, 33. [CrossRef]

163. Aiyyer, A.; Molinari, J. MJO and tropical cyclognesis in the Gulf of Mexico and easternPacific: Case study and idealized numerical modeling. J. Atmos. Sci. 2008, 65, 2691-2704. [CrossRef]

164. Rydbeck, A.V.; Maloney, E.D. On the Convective Coupling and Moisture Organization of East Pacific Easterly Waves. J. Atmos. Sci. 2015, 72, 3850-3870. [CrossRef]

165. Jury, M.R.; Rios-Berrios, R.; Garcia, E. Caribbean hurricanes: Changes of intensity and track prediction. Theor. Appl. Clim. 2011, 107, 297-311. [CrossRef]

166. Guo, Y.; Jiang, X.; Waliser, D.E. Modulation of the Convectively Coupled Kelvin Waves over South America and the Tropical Atlantic Ocean in Association with the Madden-Julian Oscillation. J. Atmos. Sci. 2014, 71, 1371-1388. [CrossRef]

167. Jury, M.R. MJO influence in the Caribbean. Theor. Appl. Clim. 2019, 139, 1559-1567. [CrossRef]

168. Zhao, Z.; Oliver, E.C.J.; Ballestero, D.; Vargas-Hernandez, J.M.; Holbrook, N.J. Influence of the Madden-Julian oscillation on Costa Rican mid-summer drought timing. Int. J. Clim. 2018, 39, 292-301. [CrossRef]

169. Trenberth, K.E.; Hoar, T.J. El Niño and climate change. Geophys. Res. Lett. 1997, 24, 3057-3060. [CrossRef]

170. Dai, A.; Wigley, T.M.L. Global patterns of ENSO-induced precipitation. Geophys. Res. Lett. 2000, 27, $1283-1286$. [CrossRef]

171. Magaña, V.O.; Vazquez, J.L.; Perez, J.L.; Perez, J.B. Impact of El Niño on precipitation in Mexico. Geofísica Int. 2003, 42, 313-330.

172. Amador, J.A.; Durán-Quesada, A.M.; Rivera, E.R.; Mora, G.; Sáenz, F.; Calderón, B.; Mora, N. The easternmost tropical Pacific. Part II: Seasonal and intraseasonal modes of atmospheric variability. Rev. De Biol. Trop. 2016, 64, 23-57. [CrossRef]

173. Maldonado, T.; Alfaro, E.J.; Fallas-López, B.; Alvarado, L. Seasonal prediction of extreme precipitation events and frequency of rainy days over Costa Rica, Central America, using Canonical Correlation Analysis. Adv. Geosci. 2013, 33, 41-52. [CrossRef]

174. Melgarejo, A.E.; Ordoñez-Peréz, P.; Nieto, R.; Gimeno, L.; Ribera, P. Moisture transport related to the ENSO effects in the Mexican precipitation. In Proceedings of the First International Electronic Conference on the Hydrological Cycle; MDPI: Basel, Switzerland, 2017; p. 4884.

175. Bhattacharya, T.; Chiang, J.C.H. Spatial variability and mechanisms underlying El Niño-induced droughts in Mexico. Clim. Dyn. 2014, 43, 3309-3326. [CrossRef]

176. Tang, B.H.; Neelin, J.D. ENSO Influence on Atlantic hurricanes via tropospheric warming. Geophys. Res. Lett. 2004, 31. [CrossRef]

177. Krishnamurthy, L.; Vecchi, G.A.; Msadek, R.; Murakami, H.; Wittenberg, A.T.; Zeng, F. Impact of Strong ENSO on Regional Tropical Cyclone Activity in a High-Resolution Climate Model in the North Pacific and North Atlantic Oceans. J. Clim. 2016, 29, 2375-2394. [CrossRef]

178. Camargo, S.J.; Emanuel, K.A.; Sobel, A.H. Use of a Genesis Potential Index to Diagnose ENSO Effects on Tropical Cyclone Genesis. J. Clim. 2007, 20, 4819-4834. [CrossRef]

179. Bello, O.; Malavassi, L.M.O.; Samaniego, J. La estimación de los efectos de los desastres en América Latina, 1972-2010. In Serie Medio Ambiente y Desarrollo N 157; CEPAL: Santiago, CL, USA, 2014.

180. Chiang, J.C.H.; Vimont, D.J. Analagous meridional modes of atmosphere-ocean variability in the tropical Pacific and tropical Atlantic. J. Clim. 2004, 17, 4143-4158. [CrossRef]

181. Vimont, D.J.; Kossin, J.P. The Atlantic Meridional Mode and hurricane activity. Geophys. Res. Lett. $2007,34$. [CrossRef]

182. Patricola, C.M.; Saravanan, R.; Chang, P. The Impact of the El Niño-Southern Oscillation and Atlantic Meridional Mode on Seasonal Atlantic Tropical Cyclone Activity. J. Clim. 2014, 27, 5311-5328. [CrossRef]

183. Lim, Y.-K.; Schubert, S.D.; Reale, O.; Molod, A.M.; Suarez, M.J.; Auer, B.M. Large-Scale Controls on Atlantic Tropical Cyclone Activity on Seasonal Time Scales. J. Clim. 2016, 29, 6727-6749. [CrossRef] 
184. Colbert, A.J.; Soden, B. Climatological Variations in North Atlantic Tropical Cyclone Tracks. J. Clim. 2012, 25, 657-673. [CrossRef]

185. Wallace, J.M.; Gutzler, D.S. Teleconnections in the Geopotential Height Field during the Northern Hemisphere Winter. Mon. Weather Rev. 1981, 109, 784-812. [CrossRef]

186. Jury, M.R.; Malmgren, B.A.; Winter, A. Subregional precipitation climate of the Caribbean and relationships with ENSO and NAO. J. Geophys. Res. Space Phys. 2007, 112. [CrossRef]

187. Rodriguez-Vera, G.; Romero-Centeno, R.; Castro, C.L.; Castro, V.M. Coupled Interannual Variability of Wind and Sea Surface Temperature in the Caribbean Sea and the Gulf of Mexico. J. Clim. 2019, 32, 4263-4280. [CrossRef]

188. Gouirand, I.; Jury, M.R.; Sing, B. An Analysis of Low- and High-Frequency Summer Climate Variability around the Caribbean Antilles. J. Clim. 2012, 25, 3942-3952. [CrossRef]

189. Vimont, D.J. The Contribution of the Interannual ENSO Cycle to the Spatial Pattern of Decadal ENSO-Like Variability. J. Clim. 2005, 18, 2080-2092. [CrossRef]

190. Mantua, N.J.; Hare, S.R.; Zhang, Y.; Wallace, J.M.; Francis, R.C. A Pacific decadal climate oscillation with impacts on salmon. Bull. Am. Meteor. Soc. 1997, 78, 1069-1079. [CrossRef]

191. Maldonado, T.; Rutgersson, A.; Amador, J.; Alfaro, E.; Claremar, B. Variability of the Caribbean low-level jet during boreal winter: Large-scale forcings. Int. J. Clim. 2015, 36, 1954-1969. [CrossRef]

192. Pavia, E.G.; Graef, F.; Reyes, J. PDO-ENSO Effects in the Climate of Mexico. J. Clim. 2006, 19, 6433-6438. [CrossRef]

193. Méndez, M.; Magaña, V. Regional Aspects of Prolonged Meteorological Droughts over Mexico and Central America. J. Clim. 2010, 23, 1175-1188. [CrossRef]

194. Delworth, T.L.; Mann, M.E. Observed and simulated multidecadal variability in the Northern Hemisphere. Clim. Dyn. 2000, 16, 661-676. [CrossRef]

195. Ribera, P.; Ordoñez, P.; Gallego, D.; Peña-Ortiz, C. Internal variability and external forcings in the ocean-atmosphere multidecadal oscillator over the North Atlantic. Clim. Dyn. 2020, 1-15. [CrossRef]

196. Ashby, S.A.; Taylor, M.A.; Chen, A.A. Statistical models for predicting rainfall in the Caribbean. Theor. Appl. Clim. 2005, 82, 65-80. [CrossRef]

197. Maldonado, T.; Alfaro, E.J.; Hidalgo, H.G. A review of the main drivers and variability of Central America's Climate and seasonal forecast systems. Rev. De Biol. Trop. 2018, 66, 153-175. [CrossRef]

198. Goldenberg, S.B.; Landsea, C.W.; Mestas-Nuñez, A.M.; Gray, W.M. The Recent Increase in Atlantic Hurricane Activity: Causes and Implications. Science 2001, 293, 474-479. [CrossRef]

199. Mendez-Gonzalez, J.; Ramirez, L.A.; Cornejo, O.E.; Zárate, L.A.; Cavazos, P.T. Investigaciones Geográficas, Boletín del Instituto de Geografía; UNAM: Mexico City, Mexico, 2010; Volume 73, pp. 57-70, ISSN 0188-4611.

200. Ravelo, A.C.; Andreasen, D.H.; Lyle, M.; Lyle, A.O.; Wara, M.W. Regional climate shifts caused by gradual global cooling in the Pliocene epoch. Nature 2004, 429, 263-267. [CrossRef] [PubMed]

201. Karas, C.; Nürnberg, D.; Bahr, A.; Groeneveld, J.; Herrle, J.O.; Tiedemann, R.; Demenocal, P.B. Pliocene oceanic seaways and global climate. Sci. Rep. 2017, 7, 39842. [CrossRef] [PubMed]

202. Auderset, A.; Martínez-García, A.; Tiedemann, R.; Hasenfratz, A.P.; Eglinton, T.I.; Schiebel, R.; Sigman, D.M.; Haug, G.H. Gulf Stream intensification after the early Pliocene shoaling of the Central American Seaway. Earth Planet. Sci. Lett. 2019, 520, 268-278. [CrossRef]

203. Peterson, L.C.; Haug, G.H. Variability in the mean latitude of the Atlantic Intertropical Convergence Zone as recorded by riverine input of sediments to the Cariaco Basin (Venezuela). Palaeogeogr. Palaeoclim. Palaeoecol. 2006, 234, 97-113. [CrossRef]

204. Richey, J.N.; Poore, R.Z.; Flower, B.P.; Quinn, T.M.; Hollander, D.J. Regionally coherent Little Ice Age cooling in the Atlantic Warm Pool. Geophys. Res. Lett. 2009, 36. [CrossRef]

205. Benway, H.M.; Mix, A.C.; Haley, B.A.; Klinkhammer, G. Eastern Pacific Warm Pool paleosalinity and climate variability: 0-30 kyr. Paleoceanography 2006, 21. [CrossRef]

206. LeDuc, G.; Vidal, L.; Tachikawa, K.; Rostek, F.; Sonzogni, C.; Beaufort, L.; Bard, E. Moisture transport across Central America as a positive feedback on abrupt climatic changes. Nature 2007, 445, 908-911. [CrossRef]

207. Lachniet, M.; Johnson, L.; Asmerom, Y.; Burns, S.J.; Polyak, V.J.; Patterson, W.P.; Burt, L.; Azouz, A. Late Quaternary moisture export across Central America and to Greenland: Evidence for tropical rainfall variability from Costa Rican stalagmites. Quat. Sci. Rev. 2009, 28, 3348-3360. [CrossRef] 
208. Winter, A.; Zanchettin, D.; Lachniet, M.; Vieten, R.; Pausata, F.S.R.; Ljungqvist, F.C.; Cheng, H.; Edwards, R.L.; Miller, T.; Rubinetti, S.; et al. Initiation of a stable convective hydroclimatic regime in Central America circa 9000 years BP. Nat. Commun. 2020, 11, 1-8. [CrossRef] [PubMed]

209. Pollock, A.; Van Beynen, P.; Delong, K.; Polyak, V.J.; Asmerom, Y.; Reeder, P. A mid-Holocene paleoprecipitation record from Belize. Palaeogeogr. Palaeoclim. Palaeoecol. 2016, 463, 103-111. [CrossRef]

210. Wu, J.; Porinchu, D.F.; Horn, S.P. Late Holocene hydroclimate variability in Costa Rica: Signature of the terminal classic drought and the Medieval Climate Anomaly in the northern tropical Americas. Quat. Sci. Rev. 2019, 215, 144-159. [CrossRef]

211. Linsley, B.K.; Dunbar, R.B.; Wellington, G.M.; Mucciarone, D.A. A coral-based reconstruction of Intertropical Convergence Zone variability over Central America since 1707. J. Geophys. Res. Space Phys. 1994, 99, 9977. [CrossRef]

212. Akers, P.D.; Brook, G.A.; Railsback, L.B.; Liang, F.; Iannone, G.; Webster, J.W.; Reeder, P.P.; Cheng, H.; Edwards, R.L. An extended and higher-resolution record of climate and land use from stalagmite MC01 from Macal Chasm, Belize, revealing connections between major dry events, overall climate variability, and Maya sociopolitical changes. Palaeogeogr. Palaeoclim. Palaeoecol. 2016, 459, 268-288. [CrossRef]

213. Hodell, D.A.; Brenner, M.; Curtis, J.H. Terminal Classic drought in the northern Maya lowlands inferred from multiple sediment cores in Lake Chichancanab (Mexico). Quat. Sci. Rev. 2005, 24, 1413-1427. [CrossRef]

214. Lewis, S.L.; Maslin, M.A. Defining the Anthropocene. Nature 2015, 519, 171-180. [CrossRef]

215. Falkowski, P. The Global Carbon Cycle: A Test of Our Knowledge of Earth as a System. Science 2000, 290, 291-296. [CrossRef]

216. Fang, J.; Zhu, J.; Wang, S.; Yue, C.; Shen, H. Global warming, human-induced carbon emissions, and their uncertainties. Sci. China Earth Sci. 2011, 54, 1458-1468. [CrossRef]

217. Summerhayes, C.P.; Zalasiewicz, J. Global warming and the Anthropocene. Geol. Today 2018, 34, $194-200$. [CrossRef]

218. Previdi, M.; Liepert, B.G.; Peteet, D.; Hansen, J.; Beerling, D.J.; BroccoliiD, A.J.; Frolking, S.; Galloway, J.N.; Heimann, M.; Le Quéré, C.; et al. Climate sensitivity in the Anthropocene. Q. J. R. Meteorol. Soc. 2013, 139, 1121-1131. [CrossRef]

219. Van Loon, A.F.; Gleeson, T.; Clark, J.; Van Dijk, A.I.J.M.; Stahl, K.; Hannaford, J.; Di Baldassarre, G.; Teuling, A.J.; Tallaksen, L.M.; Uijlenhoet, R.; et al. Drought in the Anthropocene. Nat. Geosci. 2016, 9, 89-91. [CrossRef]

220. Herrera, D.A.; Ault, T.R.; Fasullo, J.T.; Coats, S.; Carrillo, C.M.; Cook, B.I.; Williams, A.P. Exacerbation of the 2013-2016 Pan-Caribbean Drought by Anthropogenic Warming. Geophys. Res. Lett. 2018, 45, 10619-10626. [CrossRef] [PubMed]

221. Malhi, Y.; Gardner, T.A.; Goldsmith, G.R.; Silman, M.R.; Zelazowski, P. Tropical Forests in the Anthropocene. Annu. Rev. Environ. Resour. 2014, 39, 125-159. [CrossRef]

222. Utting, P. Deforestation in Central America: Historical and Contemporary Dynamics. In Sustainable Agriculture in Central America; Springer Science and Business Media LLC.: Berlin, Germany, 1997; pp. 9-29.

223. Valle, N.T.; Islebe, G.A.; Roy, P.D. Introduction: The Holocene and Anthropocene Environmental History of Mexico. In The Holocene and Anthropocene Environmental History of Mexico; Springer Science and Business Media LLC.: Berlin, Germany, 2019; pp. 1-5.

224. Zinn, J.O. Living in the Anthropocene: Towards a risk-taking society. Environ. Sociol. 2016, 2, 385-394. [CrossRef]

225. Frame, D.J.; Harrington, L.J.; Fuglestvedt, J.S.; Millar, R.J.; Joshi, M.M.; Caney, S.; Frame, D.J. Emissions and emergence: A new index comparing relative contributions to climate change with relative climatic consequences. Environ. Res. Lett. 2019, 14, 084009. [CrossRef]

226. Aguilar, E.; Peterson, T.C.; Obando, P.R.; Frutos, R.; Retana, J.A.; Solera, M.; Soley, J.; García, I.G.; Araujo, R.M.; Santos, A.R.; et al. Changes in precipitation and temperature extremes in Central America and northern South America, 1961-2003. J. Geophys. Res. Space Phys. 2005, 110. [CrossRef]

227. Pavia, E.G.; Graef, F.; Reyes, J. Annual and seasonal surface air temperature trends in Mexico. Int. J. Clim. 2009, 29, 1324-1329. [CrossRef]

228. Navarro-Estupinan, J.; Morua, A.R.; Vivoni, E.R.; Zepeda, J.E.; Montoya, J.; Verduzco, V.S. Observed trends and future projections of extreme heat events in Sonora, Mexico. Int. J. Clim. 2018, 38, 5168-5181. [CrossRef] 
229. Stephenson, T.S.; Vincent, L.A.; Allen, T.; Van Meerbeeck, C.J.; McLean, N.; Peterson, T.C.; Taylor, M.A.; Aaron-Morrison, A.P.; Auguste, T.; Bernard, D.; et al. Changes in extreme temperature and precipitation in the Caribbean region, 1961-2010. Int. J. Clim. 2014, 34, 2957-2971. [CrossRef]

230. Jones, P.D.; Harpham, C.; Harris, I.; Goodess, C.M.; Burton, A.; Centella-Artola, A.; Taylor, M.A.; Bezanilla-Morlot, A.; Campbell, J.D.; Stephenson, T.S.; et al. Long-term trends in precipitation and temperature across the Caribbean. Int. J. Clim. 2015, 36, 3314-3333. [CrossRef]

231. Peterson, T.C.; Demeritte, R.; Duncombe, D.L.; Burton, S.; Thompson, F.; Porter, A.; Mercedes, M.; Fils, R.S.; Tank, A.M.G.K.; Martis, A.; et al. Recent changes in climate extremes in the Caribbean region. J. Geophys. Res. Space Phys. 2002, 107. [CrossRef]

232. Anderson, T.G.; Anchukaitis, K.J.; Pons, D.; Taylor, M. Multiscale trends and precipitation extremes in the Central American Midsummer Drought. Environ. Res. Lett. 2019, 14, 124016. [CrossRef]

233. Ruiz-Alvarez, O.; Singh, V.P.; Enciso-Medina, J.; Ontiveros-Capurata, R.E.; Santos, C.A.C. Observed trends in daily extreme precipitation indices in Aguascalientes, Mexico. Meteorol. Appl. 2019, 27. [CrossRef]

234. Arriaga-Ramírez, S.; Cavazos, T. Regional trends of daily precipitation indices in northwest Mexico and southwest United States. J. Geophys. Res. Space Phys. 2010, 115. [CrossRef]

235. Brienen, R.J.W.; Hietz, P.; Wanek, W.; Gloor, M. Oxygen isotopes in tree rings record variation in precipitation $\delta 18 \mathrm{O}$ and amount effects in the south of Mexico. J. Geophys. Res. Biogeosci. 2013, 118, 1604-1615. [CrossRef]

236. Moss, R.H.; Edmonds, J.A.; Hibbard, K.A.; Manning, M.R.; Rose, S.K.; Van Vuuren, D.; Carter, T.R.; Emori, S.; Kainuma, M.; Kram, T.; et al. The next generation of scenarios for climate change research and assessment. Nature 2010, 463, 747-756. [CrossRef]

237. Van Vuuren, D.; Edmonds, J.; Kainuma, M.; Riahi, K.; Thomson, A.; Hibbard, K.; Hurtt, G.C.; Kram, T.; Krey, V.; Lamarque, J.-F.; et al. The representative concentration pathways: An overview. Clim. Chang. 2011, 109, 5-31. [CrossRef]

238. Meehl, G.A.; Covey, C.; Delworth, T.; Latif, M.; McAvaney, B.; Mitchell, J.F.; Stouffer, R.J.; Taylor, K.E. The WCRP CMIP3 multimodel dataset: A new era in climate change research. Bull. Am. Meteorol. Soc. 2007, 88, 1383-1394. [CrossRef]

239. Taylor, K.E.; Stouffer, R.J.; Meehl, G.A. An Overview of CMIP5 and the Experiment Design. Bull. Am. Meteorol. Soc. 2012, 93, 485-498. [CrossRef]

240. Eyring, V.; Bony, S.; Meehl, G.A.; Senior, C.A.; Stevens, B.; Stouffer, R.J.; Taylor, K.E. Overview of the Coupled Model Intercomparison Project Phase 6 (CMIP6) experimental design and organization. Geosci. Model Dev. 2016, 9, 1937-1958. [CrossRef]

241. Maurer, E.P.; Roby, N.; Stewart-Frey, I.T.; Bacon, C.M. Projected twenty-first-century changes in the Central American mid-summer drought using statistically downscaled climate projections. Reg. Environ. Chang. 2017, 17, 2421-2432. [CrossRef]

242. Nakaegawa, T.; Kitoh, A.; Ishizaki, Y.; Kusunoki, S.; Murakami, H. Caribbean low-level jets and accompanying moisture fluxes in a global warming climate projected with CMIP3 multi-model ensemble and fine-mesh atmospheric general circulation models. Int. J. Clim. 2013, 34, 964-977. [CrossRef]

243. Cabos, W.; Sein, D.; Durán-Quesada, A.; Liguori, G.; Koldunov, N.; Martinez-Lopez, B.; Alvarez, F.; Sieck, K.; Limareva, N.; Pinto, J.G. Dynamical downscaling of historical climate over CORDEX Central America domain with a regionally coupled atmosphere-ocean model. Clim. Dyn. 2018, 52, 4305-4328. [CrossRef]

244. Cavazos, T.; Luna-Niño, R.; Cerezo-Mota, R.; Fuentes-Franco, R.; Méndez, M.; Martínez, L.F.P.; Valenzuela, E. Climatic trends and regional climate models intercomparison over the CORDEX-CAM (Central America, Caribbean, and Mexico) domain. Int. J. Clim. 2019, 40, 1396-1420. [CrossRef]

245. Campbell, J.D.; Taylor, M.A.; Stephenson, T.S.; Watson, R.A.; Whyte, F.S. Future climate of the Caribbean from a regional climate model. Int. J. Clim. 2010, 31, 1866-1878. [CrossRef]

246. Karmalkar, A.V.; Taylor, M.A.; Campbell, J.; Stephenson, T.; New, M.; Centella, A.; Benzanilla, A.; Charlery, J. A review of observed and projected changes in climate for the islands in the Caribbean. Atmósfera 2013, 26, 283-309. [CrossRef]

247. McLean, N.M.; Stephenson, T.S.; Taylor, M.A.; Campbell, J.D. Characterization of Future Caribbean Rainfall and Temperature Extremes across Rainfall Zones. Adv. Meteorol. 2015, 2015, 1-18. [CrossRef] 
248. Imbach, P.; Chou, S.C.; Lyra, A.A.; Rodrigues, D.; Latinovic, D.; Siqueira, G.; Silva, A.; Garofolo, L.; Georgiou, S.; Rodriguez, D.A. Future climate change scenarios in Central America at high spatial resolution. PLoS ONE 2018, 13, e0193570. [CrossRef]

249. Neelin, J.D.; Munnich, M.; Su, H.; Meyerson, J.E.; Holloway, C.E. Tropical drying trends in global warming models and observations. Proc. Natl. Acad. Sci. USA 2006, 103, 6110-6115. [CrossRef]

250. Magrin, G.O.; Marengo, J.-P.; Boulanger, M.S.; Buckeridge, E.; Castellanos, G.; Poveda, F.R.; Scarano, S. Vicuña, 2014: Central and South America. In Climate Change 2014: Impacts, Adaptation, and Vulnerability. Part B: Regional Aspects. Contribution of Working Group II to the Fifth Assessment Report of the Intergovernmental Panel on Climate Change; Cambridge University Press: Cambridge, UK; New York, NY, USA; pp. 1499-1566.

251. Fábrega, J.; Nakaegawa, T.; Pinzón, R.; Nakayama, K.; Arakawa, O.; SOUSEI Theme-C Modeling Group. Hydroclimate projections for Panama in the late 21st Century. Hydrol. Res. Lett. 2013, 7, 23-29. [CrossRef]

252. Flores, R.A.R.; Taddia, A.P.; Grunwaldt, A.; Jones, R.; Streeter, R. Climate Change Projections in Latin America and the Caribbean: Review of Existing Regional Climate Models' Outputs; Inter-American Development Bank: Washington, DC, USA, 2016.

253. Colorado-Ruiz, G.; Cavazos, T.; Salinas, J.A.; De Grau, P.; Ayala, R. Climate change projections from Coupled Model Intercomparison Project phase 5 multi-model weighted ensembles for Mexico, the North American monsoon, and the mid-summer drought region. Int. J. Clim. 2018, 38, 5699-5716. [CrossRef]

254. Adler, R.F.; Sapiano, M.R.P.; Huffman, G.J.; Wang, J.-J.; Gu, G.; Bolvin, D.T.; Chiu, L.S.; Schneider, U.; Becker, A.; Nelkin, E.; et al. The Global Precipitation Climatology Project (GPCP) Monthly Analysis (New Version 2.3) and a Review of 2017 Global Precipitation. Atmosphere 2018, 9, 138. [CrossRef] [PubMed]

255. ECLAC (Economic Commission for Latin America and the Caribbean). The Economics of Climate Change in Latin America and the Caribbean: Paradoxes and Challenges; LC/L.3895/Rev.1; United Nations: Santiago, Chile, 2014.

256. Stennett-Brown, R.K.; Stephenson, T.S.; Taylor, M.A. Caribbean climate change vulnerability: Lessons from an aggregate index approach. PLoS ONE 2019, 14, e0219250. [CrossRef] [PubMed]

257. Imbach, P.; Locatelli, B.; Zamora, J.C.; Fung, E.; Calderer, L.; Molina, L.; Ciais, P. Impacts of ClimateChange on Ecosystem Hydrological Services of Central America: Water Availability. In Climate Change Impacts on Tropical Forests in Central America: An Ecosystem Service Perspective; Aline, C., Ed.; Routledge Publishing: New York, NY, USA, 2015; pp. 65-90. ISBN 978-0-415-72080-9.

258. Lennox, J.; Ramírez, D.; Olivares, J. Climate Change in Central America: Potential Impacts and Public Policy Options. Agricultural Development and Economics of Climate Change Unit of the ECLAC Subregional Headquarters in Mexico; LC/MEX/L.1196/Rev.1; United Nations: Mexico City, Mexico, 2018-2024.

259. Lyra, A.A.; Imbach, P.; Rodriguez, D.A.; Chou, S.C.; Georgiou, S.; Garofolo, L. Projections of climate change impacts on central America tropical rainforest. Clim. Chang. 2016, 141, 93-105. [CrossRef]

260. Gohar, A.A.; Cashman, A. Modelling the impact of climate change and variability on water availability and economic likelihood: An example from the Caribbean. Wit Trans. Built Environ. 2015, 168, 1061-1072. [CrossRef]

261. Ribalaygua, J.; Gaitán, E.; Pórtoles, J.; Monjo, R. Climatic change on the Gulf of Fonseca (Central America) using two-step statistical downscaling of CMIP5 model outputs. Theor. Appl. Clim. 2017, 132, 867-883. [CrossRef]

262. Angeles-Malaspina, M.; Gonzalez, J.; Ramírez-Beltrán, N. Projections of Heat Waves Events in the Intra-Americas Region Using Multimodel Ensemble. Adv. Meteorol. 2018, 2018, 1-16. [CrossRef]

(C) 2020 by the authors. Licensee MDPI, Basel, Switzerland. This article is an open access article distributed under the terms and conditions of the Creative Commons Attribution (CC BY) license (http://creativecommons.org/licenses/by/4.0/). 